\title{
Proteomic analysis of iron acquisition, metabolic and regulatory responses of Yersinia pestis to iron starvation
}

Rembert Pieper ${ }^{1 *}$, Shih-Ting Huang ${ }^{1}$, Prashanth P Parmar ${ }^{1}$, David J Clark ${ }^{1}$, Hamid Alami ${ }^{1}$, Robert D Fleischmann ${ }^{1}$, Robert D Perry², Scott N Peterson ${ }^{1}$

\begin{abstract}
Background: The Gram-negative bacterium Yersinia pestis is the causative agent of the bubonic plague. Efficient iron acquisition systems are critical to the ability of $Y$. pestis to infect, spread and grow in mammalian hosts, because iron is sequestered and is considered part of the innate host immune defence against invading pathogens. We used a proteomic approach to determine expression changes of iron uptake systems and intracellular consequences of iron deficiency in the $Y$. pestis strain KIM6+ at two physiologically relevant temperatures $\left(26^{\circ} \mathrm{C}\right.$ and $\left.37^{\circ} \mathrm{C}\right)$.

Results: Differential protein display was performed for three $Y$. pestis subcellular fractions. Five characterized $Y$. pestis iron/siderophore acquisition systems (Ybt, Yfe, Yfu, Yiu and $\mathrm{Hmu}$ ) and a putative iron/chelate outer membrane receptor (Y0850) were increased in abundance in iron-starved cells. The iron-sulfur (Fe-S) cluster assembly system Suf, adapted to oxidative stress and iron starvation in E. coli, was also more abundant, suggesting functional activity of Suf in $Y$. pestis under iron-limiting conditions. Metabolic and reactive oxygen-deactivating enzymes dependent on Fe-S clusters or other iron cofactors were decreased in abundance in iron-depleted cells. This data was consistent with lower activities of aconitase and catalase in iron-starved vs. iron-rich cells. In contrast, pyruvate oxidase B which metabolizes pyruvate via electron transfer to ubiquinone-8 for direct utilization in the respiratory chain was strongly increased in abundance and activity in iron-depleted cells.

Conclusions: Many protein abundance differences were indicative of the important regulatory role of the ferric uptake regulator Fur. Iron deficiency seems to result in a coordinated shift from iron-utilizing to iron-independent biochemical pathways in the cytoplasm of $Y$. pestis. With growth temperature as an additional variable in proteomic comparisons of the $Y$. pestis fractions $\left(26^{\circ} \mathrm{C}\right.$ and $\left.37^{\circ} \mathrm{C}\right)$, there was little evidence for temperature-specific adaptation processes to iron starvation.
\end{abstract}

\section{Background}

Yersinia pestis, a Gram-negative bacterium, is the causative agent of the bubonic and pneumonic plague. The pathogenic lifestyle of this microbe involves two distinct life stages, one in the flea vector, the other in mammalian hosts, primarily rodents [1]. Genome sequencing and analyses have been completed for four major $Y$. pestis biovars, including the chromosome [2] and three virulence/transmission-associated plasmids $[3,4]$ of the

\footnotetext{
* Correspondence: rpieper@jcvi.org

1J. Craig Venter Institute, 9704 Medical Center Drive, Rockville, MD 20850,
} USA

(c) 2010 Pieper et al; licensee BioMed Central Ltd. This is an Open Access article distributed under the terms of the Creative Commons Attribution License (http://creativecommons.org/licenses/by/2.0), which permits unrestricted use, distribution, and reproduction in any medium, provided the original work is properly cited.
KIM strain, which belongs to the biovar mediaevalis. In addition to plasmid-encoded virulence factors, the genetically unstable chromosomal 102-kb pgm locus is also important for full virulence of $Y$. pestis in mammals and for its transmission via blocked fleas $[5,6]$. This locus encodes the yersiniabactin-dependent iron transport (Ybt) system and the hemin storage (Hms)-dependent biofilm system. Biofilm formation allows colonization of the flea proventriculus causing blockage which in turn induces active feeding behavior $[7,8]$.

Efficient iron acquisition systems are critical to the ability of Yersinia pestis to infect, spread and grow in mammalian hosts, because iron is sequestered and is

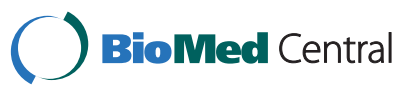


considered part of the innate host immune defence against invading pathogens [9]. The Ybt system includes a series of enzymes responsible for the siderophore's biosynthesis. Following secretion and iron chelation, the iron/yersiniabactin complex is bound by the outer membrane $(\mathrm{OM})$ receptor Psn and transferred into the periplasm via TonB-dependent energy transmission. Binding of the complex to the periplasmic surface of the inner membrane-localized ATP-binding cassette (ABC) transporter $\mathrm{YbtP} / \mathrm{YbtQ}$, which contains two permease and two ATP-binding domains, initiates iron import into the cytoplasm. A functional Ybt transporter is required for bacterial infection by subcutaneous routes and important for iron acquisition in early stages of the bubonic plague in mice [10-12]. The manganeseand iron-specific $\mathrm{ABC}$ transporter Yfe is also important for full $Y$. pestis virulence according to data from a bubonic plague mouse model [13]. Other ABC transporters for iron (Yfu and $\mathrm{Yiu}$ ) and hemin ( $\mathrm{Hmu}$ ) were functionally characterized, but were not found to be required for virulence in the mouse model [14-16]. The transporters Yfe and Feo serve somewhat redundant roles in ferrous iron uptake under microaerophilic growth conditions [17]. Genomic analysis suggests the existence of other transporters and OM receptors for iron/siderophores but have not been functionally characterized to date $[2,18]$.

The ferric uptake regulator Fur is a dominant transcription factor controlling iron assimilation in many bacterial species [19]. Iron transporters, iron storage proteins and some proteins requiring iron cofactors for function feature conserved binding sites for Fur upstream of their genes. These sites are termed Furboxes [20]. Under iron-rich conditions, Fur binds $\mathrm{Fe}^{2+}$, assumes a conformation resulting in tight binding to the Fur-box and repression of gene transcription [21]. Low iron levels result in the loss of this metal ion and allosteric conformational changes in Fur that alleviate transcriptional repression. Positive regulation by Fur in Gram-negative bacteria seems to be primarily indirect via negative transcriptional control of small RNAs [22-24]. The Fur-dependent E. coli small RNA is termed RyhB, and two RyhB orthologs were discovered in the $Y$. pestis CO92 genome [22]. E. coli RyhB controls the expression of genes whose products store iron or contain iron cofactors such as heme and iron-sulfur (Fe-S) clusters $[25,26]$. The Fe-S cluster proteins FNR, IscR and SoxR are important global regulators [27]. Some enzymes with functions in diverse branches of cellular energy metabolism [28-30] also contain Fe-S clusters. Thus, widespread changes in the proteome and metabolome of bacteria occur due to iron starvation. In E. coli, the Fur regulon was reported to overlap functionally with the regulons of the catabolite repressor protein
[31] and the oxidative stress regulator OxyR [32]. These overlaps suggest intriguing networks of metabolic interconnectivity, allowing bacterial survival and growth under iron-deficient conditions. Iron homeostasis has not been thoroughly investigated to date in $Y$. pestis. Human plasma is an iron-limiting environment, and growth condition-dependent comparisons of $Y$. pestis transcriptional patterns have included growth in human plasma [33]. Many genes involved in iron acquisition and storage and the response to oxidative stress were found to be differentially expressed [33-35]. There was reasonably good agreement between the aforementioned studies and DNA microarray data comparing a $\Delta f u r$ mutant with its $\mathrm{Fur}^{+}$parent strain [20].

Our objective was to assess iron acquisition and intracellular consequences of iron deficiency in the $Y$. pestis strain KIM6+ at two physiologically relevant temperatures $\left(26^{\circ} \mathrm{C}\right.$ and $\left.37^{\circ} \mathrm{C}\right)$. Bacterial cultures weregrown in the absence and presence of $10 \mu \mathrm{M} \mathrm{FeCl}_{3}$. Cell lysis was followed by fractionation into periplasm, cytoplasm and mixed membranes. Upon pooling of two biological replicate samples for each growth condition, proteins were analysed by differential 2D gel display. Considering the high number of distinct experimental groups (fractions) and at least three required technical 2D gel replicates per experiment for meaningful statistical analyses, the rationale for sample pooling was to keep 2D gel runs at a manageable level. Sample pooling has the disadvantage that information on quantitative variability of proteins comparing biological replicates is not obtained. Proteome analysis was performed for two equivalent growth time points (13-15 h), which represented the stationary phase for iron-replete conditions $\left(\mathrm{OD}_{600} \sim 2.0\right)$ and growth arrest at the $\mathrm{OD}_{600}$ of $\sim 0.8$ for iron-deficient conditions.

\section{Methods}

\section{Bacterial strains and culture conditions}

The $Y$. pestis strain KIM6+ used in this study is an avirulent derivative of the fully virulent KIM strain, which was cured of the $\mathrm{pCD} 1$ plasmid but retained the chromosomal pgm locus and the plasmids pMT1 and pPCP1 [36]. We used strain maintenance and cell growth procedures and verified the presence of the pgm locus on Congo Red agar as described previously [37]. Bacterial colonies were grown on tryptose blood agar at $30^{\circ} \mathrm{C}$, harvested after $48 \mathrm{~h}$ and stored at $-80^{\circ} \mathrm{C}$. Aliquots of these cell stocks were used to grow 5-10 mL cultures in chemically defined PMH2 medium [14] supplemented with $10 \mu \mathrm{M} \mathrm{FeCl}_{3}$, followed by dilution to an $\mathrm{OD}_{600}$ of $\sim 0.05$ with $0.3-1 \mathrm{~L}$ of PMH2. PMH2 was deferrated by incubation with Chelex-100 resin overnight at $4^{\circ} \mathrm{C}$ [14]. Two passages of cell stocks in 10-30 mL of this medium were followed by dilution to an $\mathrm{OD}_{600}$ of $\sim 0.05$ with 
0.3-1 L of deferrated PMH2. Overnight cell cultures (13$15 \mathrm{~h}$ ) reached $\mathrm{OD}_{600} \mathrm{~s}$ of $c a .1 .8-2.5$ and 0.6-0.9 for ironrich and iron-deficient cells, respectively. Chelex-100 treatment was previously shown to reduce contaminating iron levels to $0.2-0.3 \mu \mathrm{M}$, and replenishment of this medium with $10 \mu \mathrm{M} \mathrm{FeCl}$ resulted in full recovery of the normal $Y$. pestis growth rate and yield. Chelex-100 treatment likely removes some other metal ions as well. However, in contrast to iron, addition of $\mathrm{Mn}, \mathrm{Zn}$ and $\mathrm{Cu}$ did not enhance the observed growth rate or yield. Cell pellets were harvested by centrifugation at $8,000 \times$ $g$ for $15 \mathrm{~min}$ at $4^{\circ} \mathrm{C}$ and washed with $\mathrm{ca} .30$ volumes of $33 \mathrm{mM} \mathrm{K}_{2} \mathrm{HPO}_{4}(\mathrm{pH} 7.5)$.

\section{Subcellular fractionation of $Y$. pestis cells}

$\mathrm{K}_{2} \mathrm{HPO}_{4}$-washed $Y$. pestis cells were subjected to a lysozyme/EDTA spheroplasting method, followed by lysis of spheroplasts via sonication in a hypotonic buffer as previously described $[38,39]$. Soluble periplasmic and cytoplasmic fractions were exchanged into buffer A (25 mM $\mathrm{NH}_{4} \mathrm{HCO}_{3}, 1 \mathrm{mM} \mathrm{Na}$-EDTA and $1 \mathrm{mM}$ benzamidine) and concentrated to $2-5 \mathrm{mg} / \mathrm{mL}$ protein at $3,000 \times g$ using membrane filtration units (NMWL 10,000 ). Protein concentrations were measured with the bicinchoninic acid assay, unless stated otherwise. Mixed membrane pellets were isolated from spheroplast lysates by centrifugation at $50,000 \times g$ for $1 \mathrm{~h}$ at $4^{\circ} \mathrm{C}$. These pellets were homogenized in $0.25 \mathrm{M}$ sucrose, $150 \mathrm{mM}$ $\mathrm{NaCl}, 10 \mathrm{mM}$ Tris-OAc, pH 7.8, $5 \mathrm{mM}$ Na-EDTA, 0.2 $\mathrm{mM}$ DTT, $10 \mu \mathrm{g} / \mathrm{ml}$ Leupeptin, $5 \mu \mathrm{g} / \mathrm{ml}$ Pepstatin, 10 $\mu \mathrm{g} / \mathrm{ml} \mathrm{N} \mathrm{N}_{\alpha}$-p-Tosyl-L-arginine methyl ester and $2 \mathrm{mM}$ PMSF (ca. $10 \mathrm{~mL} / \mathrm{g}$ pellet weight), and washed to remove most soluble protein contaminants. Sodium bromide (2.5 M final concentration) was added to the suspended membrane pellet, stirred for $1 \mathrm{~h}$ at $20^{\circ} \mathrm{C}$ and centrifuged at $50,000 \times g$ for $1 \mathrm{~h}$ at $4^{\circ} \mathrm{C}$. Insoluble pellets were then extracted with an ice-cold solution of $0.18 \mathrm{M}$ $\mathrm{Na}_{2} \mathrm{CO}_{3}$, pH 11.3, $50 \mathrm{mM}$ DTT, $1 \mathrm{mM} \mathrm{CaCl} 2,1 \mathrm{mM}$ $\mathrm{MgCl}_{2}$ and $1 \mathrm{mM} \mathrm{MnCl}$, stirred for $1 \mathrm{~h}$ and spun at $50,000 \times g$ for $1 \mathrm{~h}$ at $4^{\circ} \mathrm{C}$. The supernatants were not processed further. The membrane protein-enriched pellets were solubilised with $8 \mathrm{M}$ urea, $2 \mathrm{M}$ thiourea, $1 \%$ (w/v) amidosulfobetaine 14, $2 \mathrm{mM}$ tributylphosphine and $0.5 \%$ Bio-Lyte pH 3-10 carrier ampholytes for analysis in $2 \mathrm{D}$ gels. Following incubation for $30 \mathrm{~min}$ at $20^{\circ} \mathrm{C}$ and centrifugation at $16,200 \times g$ for $15 \mathrm{~min}$, soluble aliquots of the extract, termed urea/amidosulfobetaine 14extracted membrane (usb-MBR) fraction, were run in SDS-PAGE gels. Protein amounts were estimated from Coomassie Brilliant Blue G-250 (CBB)-stained band intensities. Integral $\mathrm{OM}$ proteins were more enriched than lipoproteins and integral IM proteins. The latter proteins tend to resist solubilisation or re-precipitate during the IEF separation step.

\section{Enzyme assays}

Spectrophotometric enzyme assay were performed in 96-well microtiter plates using soluble fractions of $Y$. pestis cell lysates. Cells were harvested during the midexponential phase $\left(\mathrm{OD}_{600} \sim 0.5-0.7\right)$ and stationary phase $\left(\mathrm{OD}_{600} \sim 1.8-2.1\right)$ time points from iron-replete conditions in $\mathrm{PMH} 2$ medium at $26^{\circ} \mathrm{C}$. Cells from two equivalent time points $\left(\mathrm{OD}_{600} \sim 0.4-0.6\right.$ and $\mathrm{OD}_{600} \sim 0.7-0.9$, respectively) were harvested when growth occurred in iron-free media at $26^{\circ} \mathrm{C}$. In a $100 \mathrm{mM} \mathrm{NaH}{ }_{2} \mathrm{PO}_{4}$ buffer (pH 6.5) with $75 \mu \mathrm{g} / \mathrm{mL}$ lysozyme, $1 \mathrm{mM}$ Na-EDTA, 1 mM PMSF and $0.1 \%$ Triton X-100, cells were subjected to pressure cycling (12 cycles of $35 \mathrm{kPsi}$ for $5 \mathrm{sec}$ and 0 Psi for $20 \mathrm{sec}$ ). After the addition of $5 \mathrm{mM} \mathrm{MgCl}, 10$ $\mu \mathrm{g} / \mathrm{mL}$ DNAse I and $10 \mu \mathrm{g} / \mathrm{mL}$ RNAse cell lysates were incubated for $45 \mathrm{~min}$ at $20^{\circ} \mathrm{C}$ and centrifuged at 16,200 $\times g$ for $30 \mathrm{~min}$ at $4^{\circ} \mathrm{C}$. The supernatants were frozen at $-80^{\circ} \mathrm{C}$ in the presence of $15 \%$ glycerol until used for enzyme assays.

Pyruvate oxidase activities were determined using sodium pyruvate and $\mathrm{Na}_{3} \mathrm{Fe}(\mathrm{CN})_{6}$ as substrates and monitoring the rate of absorbance decrease of $\mathrm{Na}_{3} \mathrm{Fe}$ $(\mathrm{CN})_{6}$ at $\mathrm{A}_{450}\left(\mathrm{E}^{450}=0.218 \mathrm{~cm}^{-1} \mathrm{mM}^{-1}\right)$ while incubating at $30^{\circ} \mathrm{C}$. Cell lysates were adjusted to $\sim 0.4 \mathrm{mg} / \mathrm{mL}$ protein and assayed at pH 6.0 in $120 \mathrm{mM} \mathrm{NaH}_{2} \mathrm{PO}_{4}$ as previously reported [40], with one modification: $1 \%$ Nonidet-P40 was added to the assay buffer, because this detergent increased the activity of PoxB. Aconitase activities were determined using a coupled enzyme assay converting citrate to isocitrate and, via activity of supplemented isocitric dehydrogenase (IcdA), isocitrate to $\alpha$-ketoglutarate as previously described [41] (assay kit from Cayman Chemicals, Ann Arbor, MI). The rate of absorbance increases at $\mathrm{A}_{340}\left(\mathrm{E}^{340}=0.00622 \mathrm{~cm}^{-1}\right.$ $\mu \mathrm{M}^{-1}$ ) due to formation of the IcdA product NADPH was monitored while incubating at $37^{\circ} \mathrm{C}$. To increase the $\mathrm{pH}$ and stabilize aconitase, crude extracts were exchanged into $50 \mathrm{mM}$ Tris- $\mathrm{HCl}(\mathrm{pH} 7.5), 0.6 \mathrm{mM}$ $\mathrm{MnCl}_{2}$ and $2 \mathrm{mM}$ sodium citrate, and adjusted to $\sim 0.5$ $\mathrm{mg} / \mathrm{mL}$ protein. To distinguish the aconitase/IcdA activity from other $\mathrm{NADP}^{+}$-dependent oxidoreductive enzymes, the aconitase inhibitor oxalomalate was added at a $18.7 \mathrm{mM}$ concentration to the assay mixture. Catalase activities were determined assessing the peroxidatic function with methanol as a substrate and formaldehyde as a product in the presence of optimal concentrations of $\mathrm{H}_{2} \mathrm{O}_{2}$ at $22^{\circ} \mathrm{C}$. Crude extracts were diluted to $\sim 0.15 \mathrm{mg} / \mathrm{mL}$ protein, and formaldehyde was measured colorimetrically at $\mathrm{A}_{540}$ in an endpoint assay via addition of the chromogen 4-amino-3-hydrozino-5-mercapto-1,2,4-triazole, as previously described [42] (assay kit from Cayman Chemicals). Superoxide dismutase (SOD) activities were determined using a coupled enzyme assay measuring the dismutation of 
the superoxide radical formed by xanthine oxidase at $22^{\circ} \mathrm{C}$. The reaction was coupled to the conversion of a tetrazolium salt to formazan whose absorbance was measured at $\mathrm{A}_{450}$ in an endpoint assay as described [43] (assay kit from Cayman Chemicals). Cell lysates were diluted to $\sim 1.1 \mu \mathrm{g} / \mathrm{mL}$ protein to measure SOD activities.

\section{Protein separation and differential display in 2D gels}

Equal protein amounts from two biological replicates of periplasmic and cytoplasmic fractions were combined and diluted in a 1:5 to $1: 10$ ratio with $\mathrm{RB}$ buffer, which contained $8 \mathrm{M}$ urea, $2 \mathrm{M}$ thiourea, 4\% (w/v) CHAPS, $18 \mathrm{mM}$ DTT and 0.5\% (v/v) Bio-Lyte pH 310 carrier ampholytes. Equal protein amounts from solubilised biological replicates of mixed membrane fractions were also combined. The rationale for sample pooling is described at the end of the 'Background' section. Circa $75 \mu \mathrm{g}$ protein for Sypro Ruby ${ }^{\oplus}$-stained gels and $130 \mu \mathrm{g}$ for Coomassie Brilliant Blue G250 $(\mathrm{CBB})$-stained gels were loaded via rehydration loading onto $24 \mathrm{~cm}$ IPG gel strips ( $\mathrm{pH}$ ranges 4-7 and 3-10) and separated in the $1^{\text {st }}$ dimension as previously described [39]. Established methods were also used for $2^{\text {nd }}$ dimension slab gel electrophoresis $(25 \times 19.5 \times$ $0.15 \mathrm{~cm})$, gel staining with $\mathrm{CBB}$, scanning and gel image import into the analysis software Proteomweaver v.4.0 [44]. The scope of differential 2D display analysis was extensive, with three subcellular fractions and four growth conditions (fourteen experimental groups for seven group-to-group comparisons, among them two analyses for the periplasmic fraction with $2 \mathrm{D}$ gels in the $\mathrm{pH}$ ranges 4-7 and 6.5-10). Softwareassisted gel image analysis included spot matching, pre-match and post-match spot normalization and spot intensity averaging. The analysis mode did not require internal standards for spot normalization. The Mann-Whitney Test was used for statistical significance analysis of spot abundance changes. It is a non-parametric two sample distribution-free t-test and assesses whether two independent samples of observations come from the same distribution: $U=n 1 n 2+\frac{n 1(n 1+1)}{2}-\mathrm{R} 1$, where $\mathrm{n} 1$ and $\mathrm{n} 2$ are numbers of observations in the samples and R1 is the sum of the ranks of the observations in sample 1 . P-values determined by this test are based on $3 \leq \mathrm{n} \leq 5$ observations, which reflect $2 \mathrm{D}$ spot intensity data from an equal number of replicate gels. Provided that spot abundance ratios were $\geq 1.5$, p-values $<0.02$ were considered statistically significant. Protein spots observed in only one the two sample groups required spot matches among at least three technical replicates, but p-values could not be determined.
Mass spectrometry and bioinformatic protein analysis

Nearly all spots derived from 2D gels of the three $Y$. pestis subcellular fractions were analyzed by mass spectrometry (MS) two or more times. This was necessary in order to link each spot abundance change unambiguously to identification of a distinct protein; limitation of spot resolution in 2D gels is a known problem when the analyzed samples are highly complex. Prerequisites for confident spot identification were known protein identities of surrounding spots with equal or higher abundance and the comparison of Mascot scores in those spots. Methods for spot cutting and protein digestion with trypsin were reported previously [45]. Peptide digests were analyzed using a MALDITOFTOF mass spectrometer (4700 Proteomics Analyzer, Applied Biosystems) and a nano-electrospray LC-MS/MS system (LTQ ion trap mass spectrometer, Thermo-Finnigan, San Jose, CA) equipped with an Agilent 1100 series solvent delivery system (Agilent, Palo Alto, CA). Reversed phase peptide separations for LC-MS/MS analysis were performed at nanoflow rates (350 nL/min). Technical details of MS and $\mathrm{MS}^{2}$ analysis methods have been described [45]. The data were searched against the latest release of the $Y$. pestis KIM strain subset of the NCBInr database, using the Mascot searching engine v.2.1 (Matrix Science, London, UK). Carbamidomethyl was invariably selected as a fixed modification and one missed tryptic cleavage was allowed. MALDI search parameters ( +1 ions) included mass error tolerances of $\pm 100 \mathrm{ppm}$ for peptide precursor ions and $\pm 0.2 \mathrm{Da}$ for fragment ions. LTQ ion trap search parameters $(+1,+2$ and +3 ions $)$ included mass error tolerances of $\pm 1.4 \mathrm{Da}$ for peptide precursor ions and $\pm 0.5 \mathrm{Da}$ for fragment ions. Protein identifications were accepted as significant when Mascot protein scores $>75$ were obtained. Using a randomized decoy database, setting a default significance threshold of 0.05 in the Mascot algorithm and requiring two peptide e-values < 0.1 per protein identification, the false positive rate of proteins by LC-MS/MS was estimated to be $<0.5 \%$. Bioinformatic predictions of $Y$. pestis KIM iron transporters and binding proteins, of transmembrane domains, of protein export signal motifs and of $\beta$-barrel $\mathrm{OM}$ protein motifs were derived from the algorithms utilized in TransportDB http://www.membranetransport. org, TMHMM and SignalP http://www.cbs.dtu.dk/services and PRED-TMBB [46], respectively.

\section{Results}

Using subcellular fractionation and differential 2D gel display to assess the response of $Y$. pestis to iron starvation

Three subcellular fractions of the $Y$. pestis strain KIM6+, a periplasmic, a cytoplasmic and a membrane fraction 
enriched in integral OM proteins, were isolated from cells cultured at two growth temperatures $\left(26^{\circ} \mathrm{C}\right.$ and $37^{\circ}$ $\mathrm{C})$, without $\mathrm{FeCl}_{3}$ or supplemented with $10 \mu \mathrm{M} \mathrm{FeCl}$. Data published on the periplasmic and membrane proteomes of this strain facilitated the study $[39,44,47]$. Extensive protein identification efforts from soluble cytoplasmic fractions were performed for this study. We estimated the coverage of subcellular proteomes by comparing predicted localizations of experimentally identified proteins with those in silico assigned to the ORFs annotated in the $Y$. pestis KIM genome. The algorithm used here was PSORTb. Limiting this to the proteins clearly assigned to distinct 2D gel spots, the coverage was roughly $25 \%$ for the periplasm, $20 \%$ for the cytoplasm, $1 \%$ for the IM and $25 \%$ for the OM. The prediction of subcellular proteomes is incomplete because assignments are not made for all ORFs (e.g., $45 \%$ of the $4086 Y$. pestis KIM ORFs using PSORTb). Many proteins were not profiled quantitatively. However, subcellular fractionation allowed us to increase the number of surveyed proteins and the dynamic range of abundance measurements.

Proteome profiles derived from iron-starved and ironreplete growth conditions, often abbreviated as '-Fe and +Fe conditions' from here on, were compared. When cells were harvested, they were in the stationary phase for at least $3 \mathrm{~h}$ (+Fe conditions) or near complete growth arrest due to the lack of iron (-Fe conditions). This is visualized in growth curves at the temperatures of $37^{\circ} \mathrm{C}$ and $26^{\circ} \mathrm{C}$ provided in the graphics of Additional File 1 . Cells grown in the absence of iron at $37^{\circ} \mathrm{C}$ consistently reached a $10-20 \%$ higher $\mathrm{OD}_{600}$ than those grown at $26^{\circ} \mathrm{C}$. Earlier growth time points (exponential phase) would have been of interest, but were not included due to already extensive proteomic profiling efforts. Our rationale was that the greater difference in cell doubling times during the exponential phase (-Fe $v s$. $+\mathrm{Fe}$ ) would have confounded identification of iron starvation-specific protein changes more than that for the late growth stage.

Differential display experiments were focused on the $\mathrm{pH}$ range 4-7 in 2D gels because the majority of mature proteins have $\mathrm{pI}$ values ranging from 4 to 7 . The removal of basic $\mathrm{N}$-terminal signal sequences from exported proteins, which are displayed in the periplasmic and mixed membrane fractions, often result in a shift towards more acidic pIs. Few integral IM proteins, typically those with low $M_{r}$ values, were quantitatively profiled because TMD proteins are too hydrophobic to be sufficiently solubilised or resolved as spots in 2D gels. Periplasmic fractions consistently showed contamination with cytoplasmic proteins which was attributed to partial lysis of $Y$. pestis spheroplasts during the fractionation. The outcome of this cross-contamination was a moderately decreased depth of analysis for periplasmic proteins. Of nearly 250 statistically significant spot abundance changes with confident protein identifications, observed at $26^{\circ} \mathrm{C}$ and/or $37^{\circ} \mathrm{C}$, some were associated with spot trains. Particularly the $2 \mathrm{D}$ profile of the usb-MBR fraction featured extensive spot trains. Based on $\mathrm{MS}^{2}$ data from MALDI-TOFTOF and ESI-ion trap experiments, we have evidence that Asn and Gln amino acid side chain deamidations, which lead to acidic 2D spot shifts of proteins, account for many of the spot trains [48]. The Table of Additional File 2 lists all significant spot abundance changes (-Fe $v s$. +Fe conditions). Comprehensive MS and MS $^{2}$ datasets are provided in the Table of Additional File 3. The concise protein lists in the Tables 1, 2 and 3 are of particular interest in the context of iron homeostasis. Only if protein abundance ratios differed substantially comparing the $-\mathrm{Fe} v s$. $+\mathrm{Fe}$ datasets at $26^{\circ} \mathrm{C}$ and $37^{\circ} \mathrm{C}$, the temperature dependency was pointed out in the following paragraphs.

\section{$Y$. pestis iron acquisition systems}

Proteomic profiling of characterized $Y$. pestis iron/siderophore and heme transporters (Ybt, Yfe, Yfu, Yiu and $\mathrm{Hmu}$ ) was in good agreement with negative regulation of the respective operons by Fur and iron $[15,16,20,49,50]$. The subscript number following a protein name represents the spot number displayed in Figures 1, 2, 3 and 4, and is also denoted in the left-most column of Tables 1, 2 and 3. Periplasmic binding proteins of four of the $\mathrm{ABC}$ transporters $\left(\mathrm{YfeA}_{\# 68}, \mathrm{YfuA}_{\# 65}\right.$, $\mathrm{Yiu}_{\# 82}$ and $\mathrm{HmuT}_{\# 56}$; Figures 1 and 2) were increased in abundance in iron-starved cells. The integral IM proteins YbtP and YbtQ were identified from streaky 2D spots of the usb-MBR fraction of iron-depleted cells, but could not be differentially quantitated. Two of these five transporters have an OM receptor responsible for iron/ yersiniabactin or heme uptake $\left(\operatorname{Psn}_{\# 102}\right.$ and $\mathrm{HmuR}_{\# 95}$, respectively; Figure 3), both of which were increased in iron-starved cells. Y0850 \#96 (Figure 3) is hypothesized to be a TonB-dependent OM receptor with $\mathrm{Fe}^{3+} /$ siderophore uptake activity. This protein was also more abundant in iron-depleted cells. Detection in the usb-MBR fraction, its $\mathrm{M}_{\mathrm{r}}$ of $c a$. $75-85 \mathrm{kDa}$ and the presence of a highly conserved Fur-box upstream of the gene's transcriptional start site (AATGATAATTGATATCATT, -100 to -82 ) with a position weight matrix score of 13.2 using the patser-matrix tool [51] further supported the assignment as a Fur-regulated TonB-dependent OM receptor. Fur $\# 18$ was also detected in the cytoplasm, but not altered in abundance (Figure 4).

Abundance increases in iron-starved cells were observed for the multifunctional yersiniabactin synthase subunits HMWP1 and HMWP2 (products of the irp1 and irp 2 genes, respectively) and other enzymes 


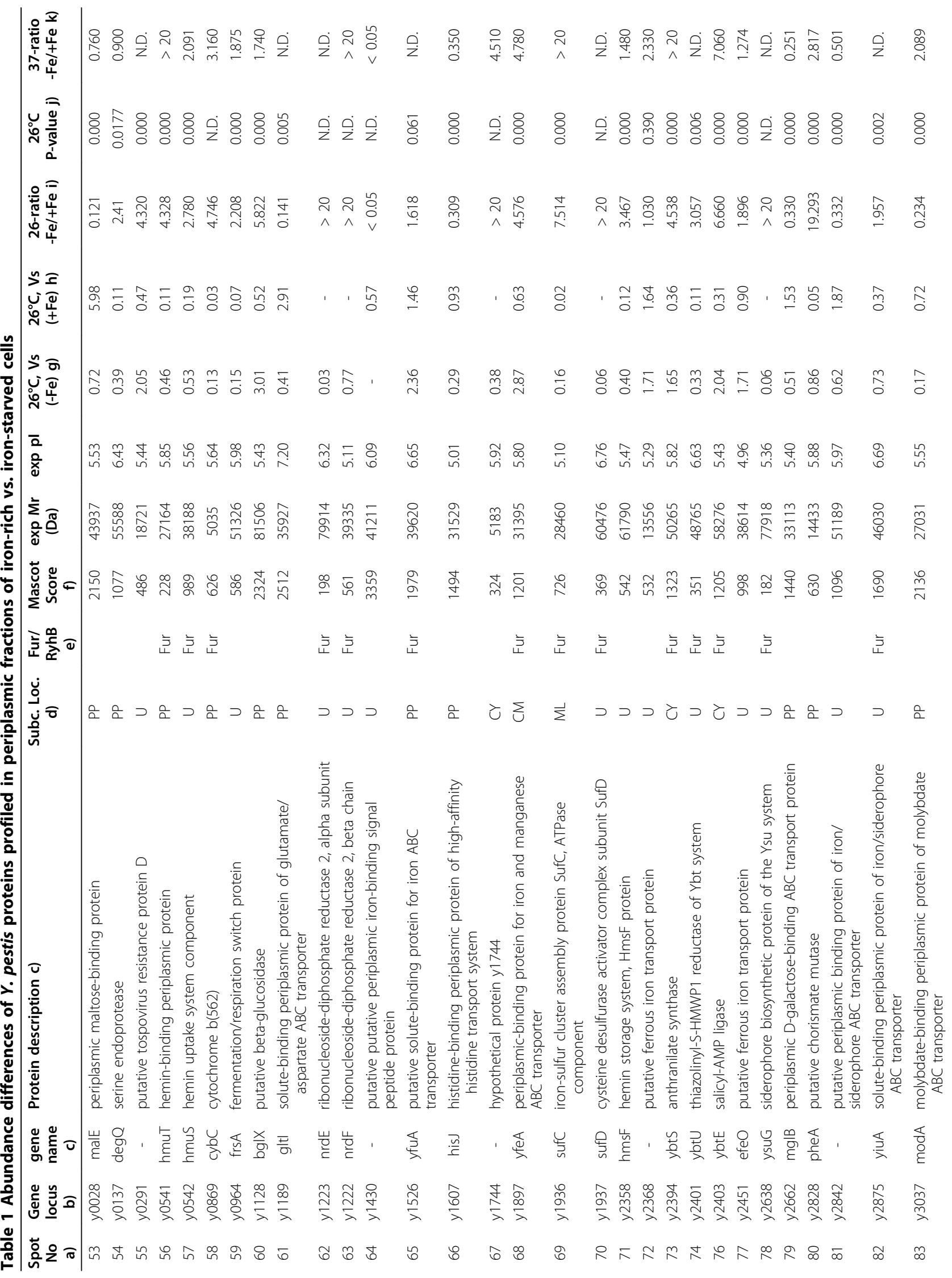




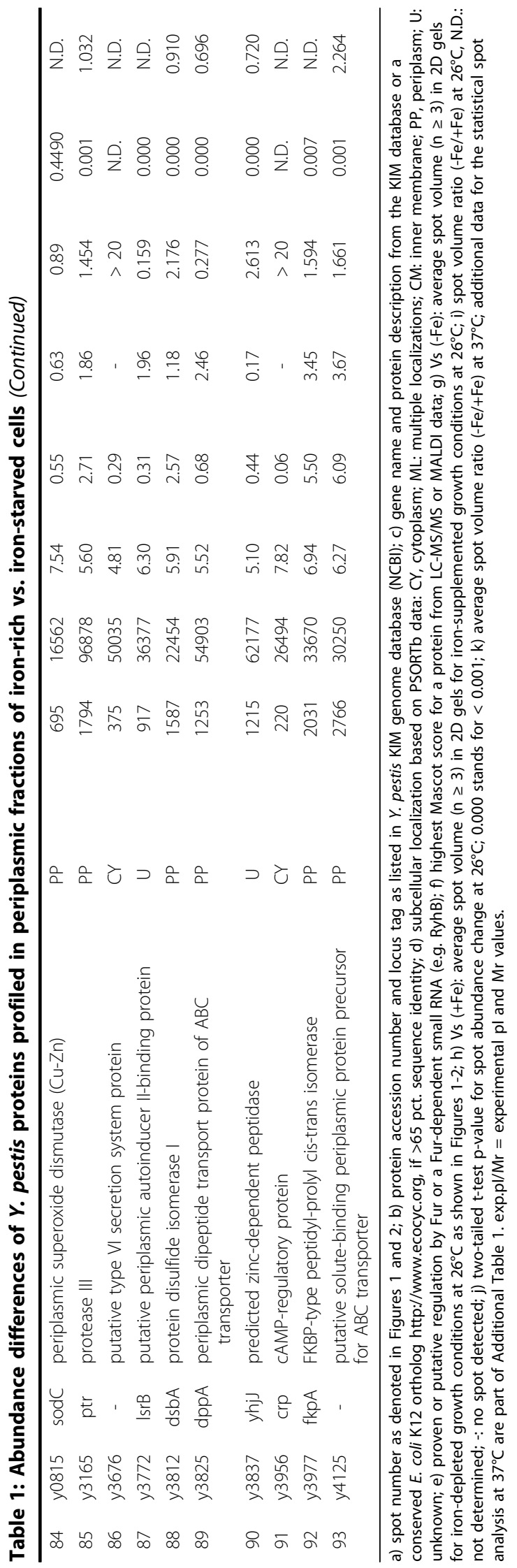

contributing to yersiniabactin biosynthesis $\left(\mathrm{YbtS}_{\# 73}\right.$, $\mathrm{YbtT}_{\# 75}, \mathrm{YbtE}_{\# 76}$ and $\left.\mathrm{YbtU}_{\# 74}\right)$. The high $\mathrm{M}_{\mathrm{r}}$ proteins HMWP1 and HMWP2 were reliably quantitated only from SDS-PAGE gels (data not shown). The ysu locus encodes an OM receptor (YsuR/Y2633), an ABC transporter (Y2634-Y2637) and a suite of siderophore biosynthetic enzymes (Y2638-Y2641). Two subunits, Y2638 \#78 (Figure 1) and $\mathrm{YsuR}_{\# 104}$ (Figure 3) were of low abundance and detected only in iron-starved cells at $26^{\circ} \mathrm{C}$. Biosynthesis of a Ysu siderophore has not been proven, and a siderophore biosynthetic pseudogene precedes the $y 2633-y 2637$ locus [18]. The OM $\beta$-barrel ferrichrome receptor $\mathrm{FcuA}_{\# 103}$ (Y2556) was identified as a protein of moderate abundance in usb-MBR fractions at $26^{\circ} \mathrm{C}$ (Figure 3) and $37^{\circ} \mathrm{C}$, but not significantly altered in abundance comparing -Fe vs. +Fe conditions. Many membrane proteins ascribed to have putative functions in iron transport were not detected, e.g. the OM receptors $\mathrm{Y} 3948$ and IutA/Y3385 and the transport systems FitA-D (Y4043-Y4046), Y2837-Y2842 and FepB/Y3477. Our data support the notion of a hierarchy of iron $\left(\mathrm{Fe}^{3}\right.$ $\left.{ }^{+}\right)$/siderophore transporters [15], with the Ybt and $\mathrm{Yfe}$ systems being dominant compared to the Yfu, Yiu and Hmu systems. Periplasmic subunits of two ferrous iron $\left(\mathrm{Fe}^{2+}\right)$ transporters, $\mathrm{EfeO} / \mathrm{Y} 2451$ and $\mathrm{Y} 2368$, were also profiled in 2D gels (Figure 1). The low $\mathrm{M}_{\mathrm{r}}$ protein Y2368 \#72 was increased in iron-starved cells at $37^{\circ} \mathrm{C}$. The tripartite $\mathrm{Fe}^{2+}$ transport protein $\mathrm{EfeO}_{\# 77}$ was increased in abundance in iron-starved cells at $26^{\circ} \mathrm{C}$.

\section{The energy metabolism of $Y$. pestis is affected by iron starvation}

Lower growth rates of $Y$. pestis in deferrated medium followed by growth arrest at $\mathrm{OD}_{600} \mathrm{~s}$ between 0.5 and 0.9 suggest perturbations of energy generation pathways. Many oxidoreductive processes are catalyzed by enzymes containing $\mathrm{Fe}-\mathrm{S}$ clusters or heme, and we sought to understand the consequences of limited iron availability as it pertains to the $Y$. pestis energy metabolism. The EcoCyc database http://www.ecocyc.org with its extensive data on E. coli energy metabolic pathways and iron cofactors of proteins was a useful resource in this context. $Y$. pestis aconitases $\mathrm{A}$ and $\mathrm{B}\left(\mathrm{AcnA}_{\# 34}\right.$ and $A c n B_{\# 8}$; Figure 4) have functions in the TCA cycle and were decreased in abundance or detected only in ironstarved cells. So were subunits of two other TCA cycle enzymes harboring Fe-S clusters $\left(\mathrm{SdhA}_{\# 43}\right.$ and FumA $\mathrm{A}_{\# 11}$; Figure 4). Some TCA cycle enzymes devoid of Fe-S clusters were decreased at moderate levels under-Fe conditions $\left(\operatorname{IcdA}_{\# 26}, \operatorname{SucA}_{\# 42}, \operatorname{SucD}_{\# 41}\right.$ and $\operatorname{SucB}_{\# 111}$; Figure 4). Strongly decreased abundances were denoted for Ace $_{\# 2}$ and $\mathrm{AceB}_{\# 1}$ (Figure 4), enzymes which catalyze the glyoxalate bypass reaction of the TCA cycle and are regulated by the catabolite repressor protein (CRP). 


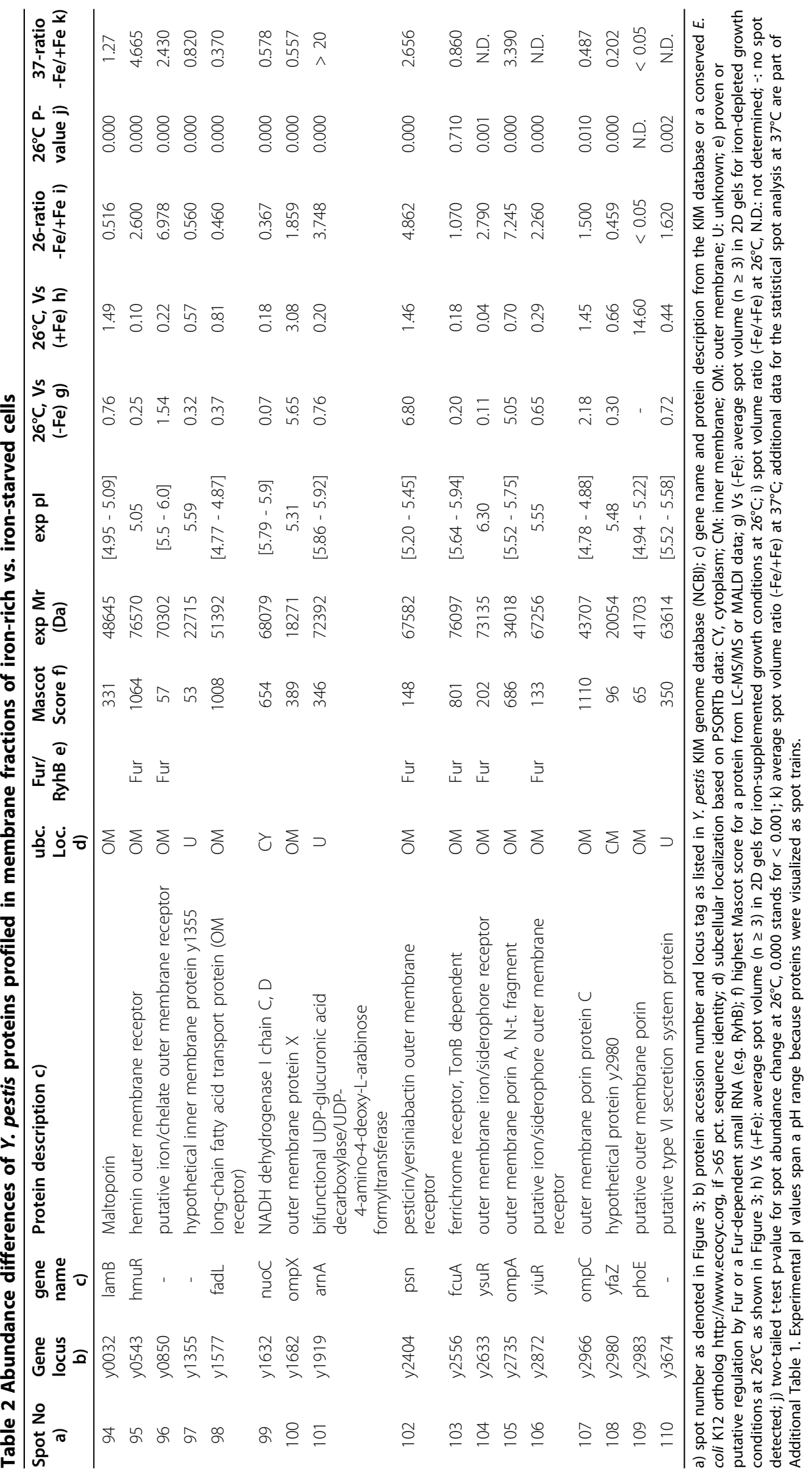




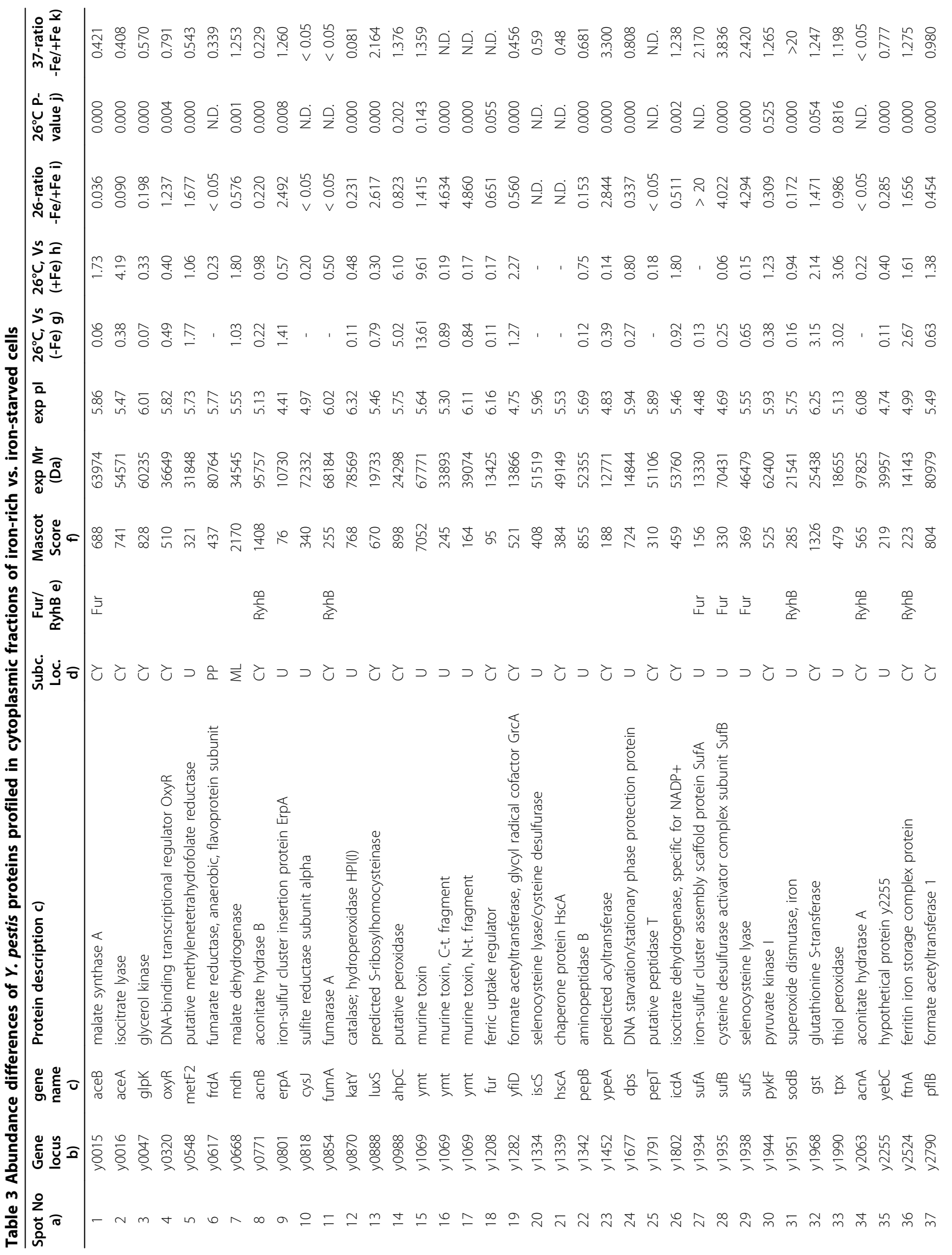




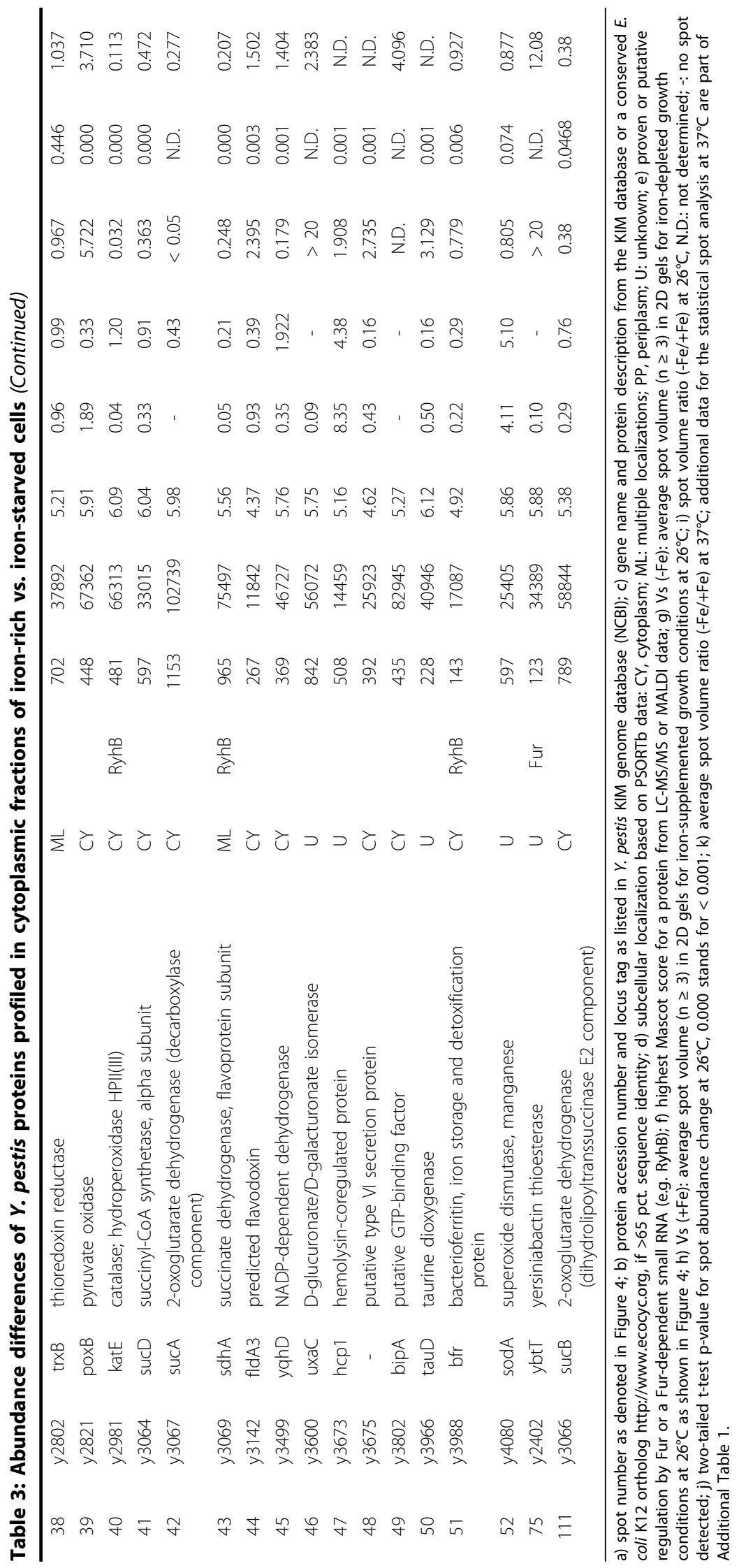



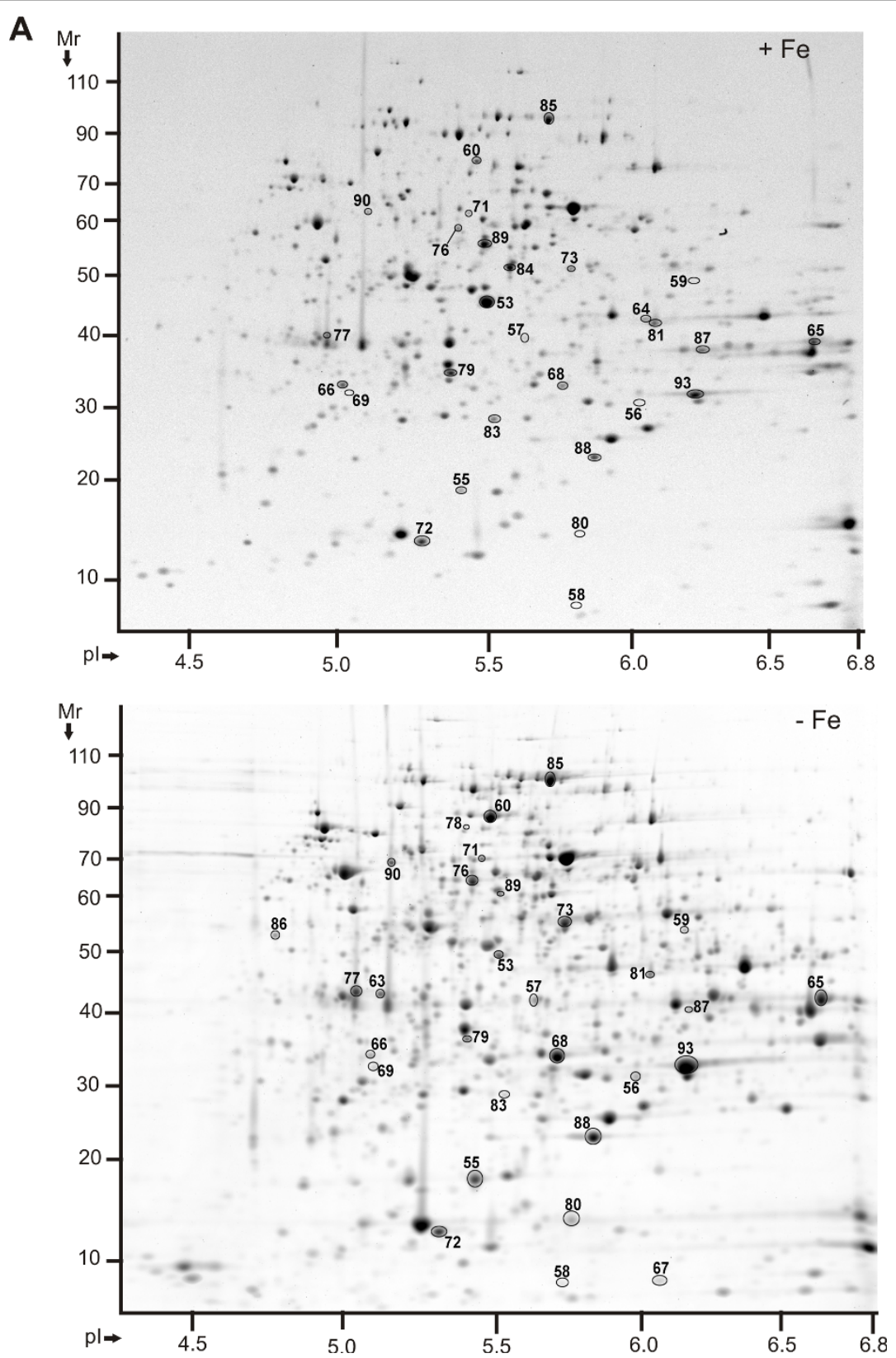

Figure 1 Protein display in 2D gels of $Y$. pestis KIM6+ periplasmic fractions in the pl range 4-7 (-Fe vs. +Fe conditions). Proteins were derived from cell growth in the presence of $10 \mu \mathrm{M} \mathrm{FeCl} 3$ at $26^{\circ} \mathrm{C}$ (top) or the absence of $\mathrm{FeCl}_{3}$ at $26^{\circ} \mathrm{C}$ (bottom). Gels $(20 \times 25 \mathrm{~cm})$ were stained with Coomassie Brilliant Blue G250 (CBB), with five gel replicates representing each group, and subjected to differential display analysis using the software Proteomweaver v.4.0. Protein assignment to a spot required validation by MS data from at least two representative gels. The denoted spot numbers are equivalent to those listed in Table 1 with their '-Fe vs. $+\mathrm{Fe}^{\prime}$ protein abundance ratios and other data.

Glycerol kinase, also regulated by CRP, was more moderately decreased in iron-starved cells $\left(\mathrm{GlpK}_{\# 3}\right.$, Figure 4). GlpK catalyzes the rate-limiting step of glycerol utilization and feeds its metabolites into the glycolytic pathway. $\mathrm{CRP}_{\# 91}$ itself was identified with low abundance in the periplasmic fraction (Figure 2). In summary, the data suggested reduced pyruvate metabolism via the citrate cycle when iron resources are exhausted in $Y$. pestis cells. Aconitase activity assays supported this assumption; the reaction rates were 2.8-fold and 2-fold higher in lysates derived from iron-replete cells $v s$. those from iron-starved cells at $26^{\circ} \mathrm{C}$ (stationary and exponential phase, respectively; Table 4).

The question arose whether iron-starved $Y$. pestis cells activated a different metabolic route of pyruvate degradation able to produce reducing equivalents (NADH 

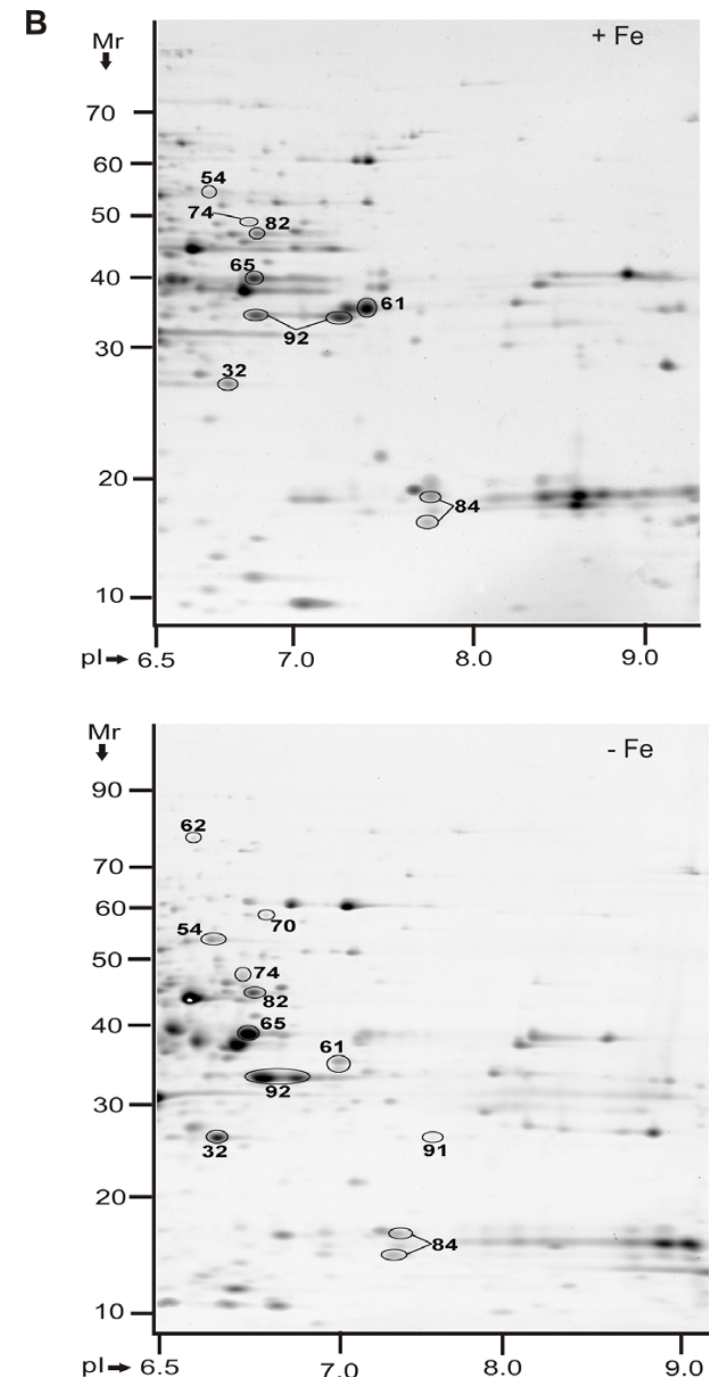

Figure 2 Protein display in 2D gels of $Y$. pestis KIM6+ periplasmic fractions in the $\mathrm{pl}$ range $6.5-9$ (-Fe vs. +Fe conditions). Proteins were derived from cell growth in the presence of $10 \mu \mathrm{M} \mathrm{FeCl}_{3}$ at $26^{\circ} \mathrm{C}$ (top) or absence of $\mathrm{FeCl}_{3}$ at $26^{\circ} \mathrm{C}$ (bottom). Gels $(20 \times 25 \mathrm{~cm})$ were stained with $\mathrm{CBB}$, with three gel replicates representing each group, and subjected to differential display analysis using the software Proteomweaver v.4.0. Protein assignment to a spot required validation by MS data from at least two representative gels. The denoted spot numbers are equivalent to those listed in Table 1 with their '-Fe vs. +Fe' protein abundance ratios and other data.

and $\mathrm{UQH}_{2}$ ) for the electron transport chain. Pyruvate oxidase (PoxB) degrades pyruvate to acetate and is a flavin-dependent, iron-independent enzyme that generates $\mathrm{UQH}_{2}$ [52]. The pyruvate oxidase pathway indeed appeared to be important, as judged by the strong abundance increase of $\mathrm{PoxB}_{\# 39}$ (Figure 4) under -Fe conditions. The flavin cofactor may be recruited from redox activities of two flavodoxins. FldA $3_{\# 44}$ was quite abundant and moderately increased in iron-depleted cells
(Figure 4). FldA was identified in faint 2D spots and not reproducibly quantitated. PoxB activity measurements revealed excellent correlation between enhanced abundances and increased reaction rates in iron-starved cells. PoxB activities were 5.3-fold and 7.8-fold higher in lysates of iron-starved cells than in lysates of ironreplete cells at $26^{\circ} \mathrm{C}$ (stationary and exponential phase, respectively; Table 4).

Electron transport chains are localized in the IM, a fact that compromised the analysis of subunits of these IM protein complexes in $2 \mathrm{D}$ gels. NuoCD $\mathrm{D}_{\# 99}$, a peripheral membrane protein of the NADH:ubiquinone oxidoreductase, was moderately decreased in abundance in iron-depleted cells (Figure 3). The E. coli NuoCD subcomplex is important for binding of some of the six Nuo-integrated Fe-S clusters [53]. Subunits of Fe-S cluster proteins with roles in two anaerobic energy metabolism branches were also less abundant in iron-depleted cells. This pertained to $\mathrm{PflB}_{\# 37}$ and $\mathrm{YfiD}_{\# 19}$, proteins of the formate-pyruvate lyase complex, and $\mathrm{FrdA}_{\# 6}$, which is part of the terminal electron acceptor fumarate reductase (Figure 4). Decreased abundances of metabolically active $\mathrm{Fe}-\mathrm{S}$ cluster enzymes were a notable feature of iron-starved $Y$. pestis proteome profiles, while the abundance and activity of PoxB suggested that this enzyme was important to maintain the aerobic energy metabolism and iron cofactor-independent generation of $\mathrm{UQH}_{2}$ in iron-deficient $Y$. pestis cells.

\section{Oxidative stress response in $Y$. pestis under iron starvation conditions}

Oxidative stress is caused by various oxygen radicals and $\mathrm{H}_{2} \mathrm{O}_{2}$, and catalyzed by redox enzymes in non-specific reactions. While the presence of free intracellular iron aggravates oxidative stress via the Fenton reaction, it is mitigated by cytoplasmic proteins that scavenge free iron, e.g. Dps and the ferritins FtnA and Bfr [54]. The question arose how aerobically growing, iron-deficient $Y$. pestis cells coped with oxidative stress. One of the main $E$. coli global regulators of the oxidative stress response, the $\mathrm{Fe}-\mathrm{S}$ cluster protein SoxR, is not encoded in the $Y$. pestis genome [2]. The other global oxidative stress response regulator is OxyR. OxyR $\mathbb{R}_{4}$ (Figure 4) was not altered in abundance in $Y$. pestis comparing -Fe and $+\mathrm{Fe}$ conditions. Among the enzymes deactivating $\mathrm{H}_{2} \mathrm{O}_{2}$ and oxygen radicals are catalases/peroxidases and superoxide dismutases (SODs). Y. pestis produces two catalases with heme cofactors in high abundance. $\mathrm{KatE}_{\# 40}$ (Y2981) was predominantly expressed at $26^{\circ} \mathrm{C}$ (Figure 4) and $\mathrm{KatY}_{\# 12}(\mathrm{Y} 0870)$ at $37^{\circ} \mathrm{C}$. Cytoplasmic SODs include $\mathrm{SodB}_{\# 31}$, which has an iron cofactor, and $\mathrm{SodA}_{\# 52}$, which has a manganese cofactor (Figure 4). Periplasmic SodC $\# 84$ has a copper/zinc cofactor (Figure 2). Iron availability-dependent patterns of abundance 

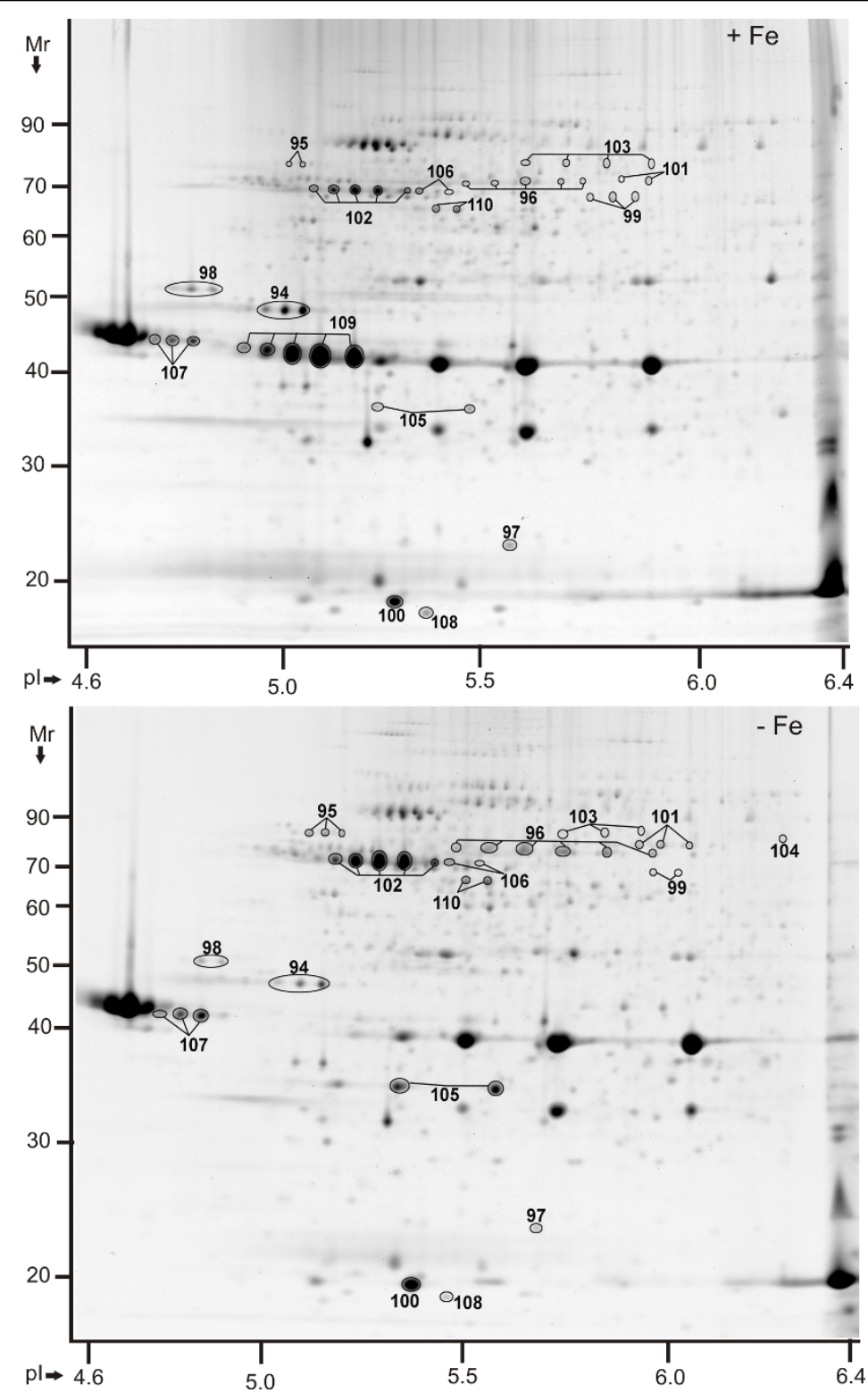

Figure 3 Protein display in 2D gels of $Y$. pestis KIM6+ membrane fractions in the pl range 4-7 (-Fe vs. +Fe conditions). Proteins were derived from cell growth in the presence of $10 \mu \mathrm{M} \mathrm{FeCl} 3$ at $26^{\circ} \mathrm{C}$ (top) or absence of FeCl 3 at $26^{\circ} \mathrm{C}$ (bottom). Gels $(20 \times 25 \mathrm{~cm})$ were stained with $\mathrm{CBB}$, with five gel replicates representing each of the groups, and subjected to differential display analysis using the software

Proteomweaver v.4.0. Protein assignments to a spot (or a spot train) required validation by MS data from at least two representative gels. The denoted spots and spot trains are equivalent to those listed in Table 2 with their '-Fe vs. +Fe' protein abundance ratios and other data.

changes reminiscent of enzymes with functions in energy metabolism were observed. Only the iron-dependent proteins KatE, KatY and SodB were strongly diminished in abundance in iron-depleted cells (Table 3). We also determined overall catalase and SOD activities. Catalase reaction rates were 3.2-fold and 2.6-fold higher in lysates derived from iron-replete $v s$. iron-starved cells at $26^{\circ} \mathrm{C}$ (stationary and exponential phase, respectively; Table 4). SOD reaction rates were 2 -fold higher in the exponential phase, but not significantly altered in the stationary phase (Table 4). This data was in good agreement with differential abundance data, although individual activities of SodA, SodB and SodC could not be discerned with the assay.

$\mathrm{AhpC}_{\# 14}, \mathrm{Tpx}_{\# 33}, \operatorname{TrxB}_{\# 38}$ and $\mathrm{Gst}_{\# 32}$, all of which are involved in redox homeostasis and deactivation of oxidative compounds, were similarly abundant in iron-rich vs. iron-starved $Y$. pestis cells (Figure 4). These enzymes contain either disulfide- or flavin-based redox centers. $\mathrm{Dps}_{\# 24}$, an iron-scavenging protein important for the 

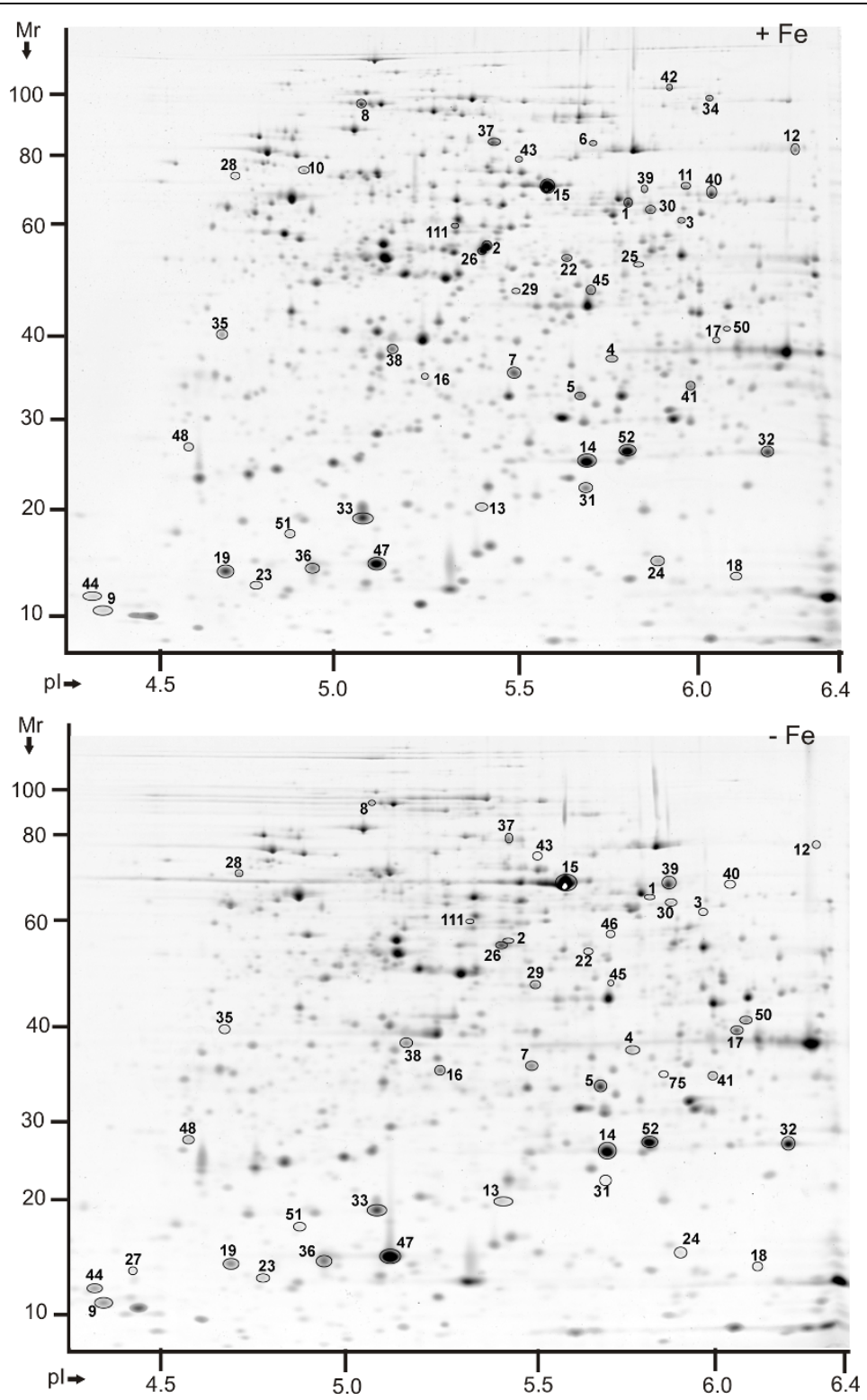

Figure 4 Protein display in 2D gels of $Y$. pestis KIM6+ cytoplasmic fractions in the pl range 4-7 (-Fe vs. +Fe conditions). Proteins were derived from cell growth in the presence of $10 \mu \mathrm{M} \mathrm{FeCl}_{3}$ at $26^{\circ} \mathrm{C}$ (top) or the absence of $\mathrm{FeCl}_{3}$ at $26^{\circ} \mathrm{C}$ (bottom). Gels $(20 \times 25 \mathrm{~cm})$ were stained with CBB, with four gel replicates representing each group, and subjected to differential display analysis using the software Proteomweaver v.4.0. Protein assignment to a spot required validation by MS data from at least two representative gels. The denoted spot numbers are equivalent to those listed in Table 3 with their '-Fe vs. +Fe' protein abundance ratios and other data.

protection and repair of DNA under general stress conditions, was moderately decreased in abundance under -Fe conditions, but only at $26^{\circ} \mathrm{C}$. The $\mathrm{OxyR} \mathrm{H}_{2} \mathrm{O}_{2}$ response system of $E$. coli was reported to restore Fur in its ability to repress gene expression in the presence of iron by increasing the protein's synthesis during oxidative stress [32], a mechanism that may be applicable to $Y$. pestis. We conclude that the bacterium adjusts its repertoire of oxidative stress response proteins when iron is in short supply, by reducing the abundance of those proteins that require iron cofactors for functional activity.

\section{Iron storage and iron-sulfur cluster biosynthesis}

in $Y$. pestis

High concentrations of free $\mathrm{Fe}^{3+}$ are toxic to bacterial cells and require sequestration by proteins. FtnA and $\mathrm{Bfr}$ are the main cytoplasmic iron storage proteins. $\mathrm{FtnA}_{\# 36}$ was slightly increased in iron-depleted cells at $26^{\circ} \mathrm{C}$ (Figure 4), but not at $37^{\circ} \mathrm{C} . \mathrm{Bfr}_{\# 51}$ (Figure 4) was of 
Table 4 Reaction rates for four $Y$. pestis enzyme classes comparing -Fe vs. +Fe conditions

\begin{tabular}{|c|c|c|c|c|c|c|}
\hline \multirow[b]{2}{*}{ Enzyme } & \multicolumn{3}{|c|}{$\begin{array}{l}\text { Reaction rate }{ }^{\mathrm{a})} \\
(\mathrm{nmol} \min -1 \mathrm{~mL}-1) ;(\mathrm{ULL}-1)^{\mathrm{b})}\end{array}$} & \multicolumn{3}{|c|}{$\begin{array}{l}\text { Reaction rate }{ }^{\text {a) }} \\
(\mathrm{nmol} \text { min-1 } \mathrm{mL}-1) ;(\mathrm{U} \mathrm{mL}-1)^{\mathrm{b})}\end{array}$} \\
\hline & $+\mathrm{Fe}, \exp , \mathrm{n}=4^{\mathrm{e})}$ & $-F e$, early, $n=5^{e)}$ & $p$-value ${ }^{f)}$ & $+\mathrm{Fe}$, stat, $\mathrm{n}=4^{\mathrm{e})}$ & -Fe, late, $n=5^{e)}$ & $p$-value ${ }^{f f}$ \\
\hline Aconitase $^{\text {c) }}$ & 2.31 & 1.14 & 0.019 & 4.98 & 1.82 & 0.008 \\
\hline$\overline{\text { Pyruvate oxidase }^{c)}}$ & 167.5 & 1307 & 0.0001 & 463.0 & 2405 & 0.0001 \\
\hline$\overline{\text { Catalase }^{\mathrm{d})}}$ & 82.5 & 31.8 & 0.0001 & 93.4 & 29.0 & 0.0001 \\
\hline Superoxide dismutase $^{\text {d) }}$ & 887.8 & 426.9 & 0.002 & 448.5 & 312.5 & 0.234 \\
\hline
\end{tabular}

a) Spectrophotometric assays in 96-well microtiter plates were used for the determination of enzyme reaction rates. Total protein concentrations in crude cell lysates were the same for all samples used in a given enzyme assay: aconitase, $0.5 \mathrm{mg} / \mathrm{mL}$; pyruvate oxidase, $0.4 \mathrm{mg} / \mathrm{mL}$; catalase, $0.15 \mathrm{mg} / \mathrm{mL}$; superoxide dismutase, $1.1 \mu \mathrm{g} / \mathrm{mL}$. ${ }^{\text {b) }}$ Units $\mathrm{ml}^{-1}$ was the definition for the superoxide dismutase reaction rate. All assays were performed in duplicate. ${ }^{\text {c) }}$ Reaction rates from the linear part of the slope of the absorbance change over time. ${ }^{d)}$ Reaction rates from endpoint assays. ${ }^{\text {e) }}$ Number of biological replicates of cell lysates ( $n$ ); exp: abbreviation for exponential, early: early growth phase equivalent to exp. phase (-Fe); average $\mathrm{OD}_{600}=0.66(+\mathrm{Fe})$ and $\mathrm{OD} 600=0.47(-\mathrm{Fe})$; stat: abbreviation for stationary growth phase, late: late growth phase equivalent to stat. phase (-Fe); average $\mathrm{OD}_{600}=2.0(+\mathrm{Fe})$ and $\mathrm{OD}_{600}=0.81(-\mathrm{Fe})$. True exponential and stationary growth phases were not observed for cell cultures in iron-free media. ${ }^{f)}$ p-values were calculated from to comparison of reaction rates (+ Fe vs. -Fe) using a two-tailed t-test method.

considerably lower abundance than FtnA and not significantly changed in abundance comparing - Fe $v s .+\mathrm{Fe}$ conditions. The $Y$. pestis KIM genome harbors two gene clusters orthologous to those of the E. coli isc and suf operons (y1333-y1341 and y1934-1939, respectively). The gene products are responsible for Fe-S cluster assembly under normal growth and stress conditions, respectively. E. coli sufABCDSE expression was reported to be controlled by the regulators OxyR (oxidative stress) and Fur (iron starvation) [55]. Protein profiling revealed that the $Y$. pestis Suf proteins were considerably increased or detected only in iron-depleted cells SufC $_{\# 69}$ and $\mathrm{SufD}_{\# 70}$, Figure 1; SufA $\# 27, \mathrm{SufB}_{\# 28}$ and the cysteine desulfurase $\mathrm{SufS}_{\# 29}$; Figure 4$)$. Four $Y$. pestis Isc subunits (IscS, NifU, HscA and $\mathrm{HscB}$ ) were detected at very low abundance in cytoplasmic fractions. The cysteine desulfurase $\mathrm{IscS}_{\# 20}$ and the chaperone $\mathrm{HscA}_{\# 21}$ were diminished in abundance in iron-starved cells at $37^{\circ} \mathrm{C}$ (Table 3 ). In contrast, an ortholog of the E. coli essential respiratory protein $\mathrm{A}\left(\operatorname{ErpA}_{\# 9}\right)$ was increased in abundance in iron-starved cells, particularly at $26^{\circ} \mathrm{C}$ (Figure 4). This low $\mathrm{M}_{\mathrm{r}} \mathrm{Fe}-\mathrm{S}$ cluster protein was proposed to serve in the transfer of Fe-S moieties to an enzyme involved in isoprenoid biosynthesis [56]. Its expression was described to be under the control of $E$. coli IscR, the regulator of the isc gene locus. However, the abundance changes of $Y$. pestis ErpA (-Fe $v s .+\mathrm{Fe})$ resemble those of the Suf rather than the Isc subunits.

The question arose whether sulfur-mobilizing proteins were also altered in abundance comparing $-\mathrm{Fe}$ and $+\mathrm{Fe}$ conditions, in order to support a Fe-S cluster rebalancing effort among proteins localized in the $Y$. pestis cytoplasm. Periplasmic binding proteins of sulfate/thiosulfate $\mathrm{ABC}$ transporters ( $\mathrm{Sbp}, \mathrm{CysP}$ ) were not altered in abundance (data not shown). The flavoprotein subunit of sulfate reductase $\left(\mathrm{Cys} \mathrm{J}_{\# 10}\right)$ was strongly decreased in abundance under iron-limiting conditions (Figure 4). CysI, the Fe-S cluster subunit, was not detected. Taurine dioxygenase however $\left(\mathrm{TauD}_{\# 50}\right.$, Figure 4$)$, which utilizes aliphatic sulfonates as a sulfur source, was increased in iron-starved $Y$. pestis cells. The E. coli dioxygenase TauD seems to require iron for activity according to a note in the EcoCyc database. Whether the activity of TauB is linked to Fe-S cluster biosynthesis or repair remains to be shown. In summary, our data supported a functional role of the $Y$. pestis Suf system in Fe-S cluster assembly when cells are deprived of iron. Data related to CysIJ suggested that Fe-S cluster proteins active in pathways unrelated to energy metabolism were also downregulated upon intracellular iron starvation.

\section{Protein abundance changes less obviously linked to iron homeostasis}

Iron is an essential cofactor for many cellular processes, and a network of global regulators (CRP, OxyR and Fur/RyhB; Figure 5) are affected by or implicated in responses to iron deficiency. We expected to detect protein abundance changes less obviously linked to iron homeostasis. S-ribosylhomocysteinase $\left(\operatorname{LuxS}_{\# 13}\right)$ is an enzyme of central importance in the activated methyl cycle and plays a role in autoinducer 2-mediated quorum sensing in E. coli [57]. The enzyme harbors tetrahedrally coordinated $\mathrm{Fe}^{2+}$ in its catalytic center. LuxS was moderately increased in iron-depleted cells at $26^{\circ} \mathrm{C}$ (Figure 4 ). In contrast, $\mathrm{LsrB}_{\# 87}$ whose E. coli ortholog facilitates periplasmic transport of the autoinducer 2 following cellular re-uptake was decreased in abundance in iron-starved cells (Figure 1), similar to $\mathrm{YebC}_{\# 35}$, a protein hypothesized to be involved in quorum sensing regulation [58]. Y. pestis has been shown to produce the autoinducer 2, although genes controlled by this system have not been identified [59]. Slightly increased abundances of four subunits of a putative type VI secretion system (T6SS) were also observed in iron-deficient $v s$. iron-rich cells. The proteins $\mathrm{HCP} 1_{\# 47}$ and $\mathrm{Y} 3675_{\# 48}$ (Figure 4), 


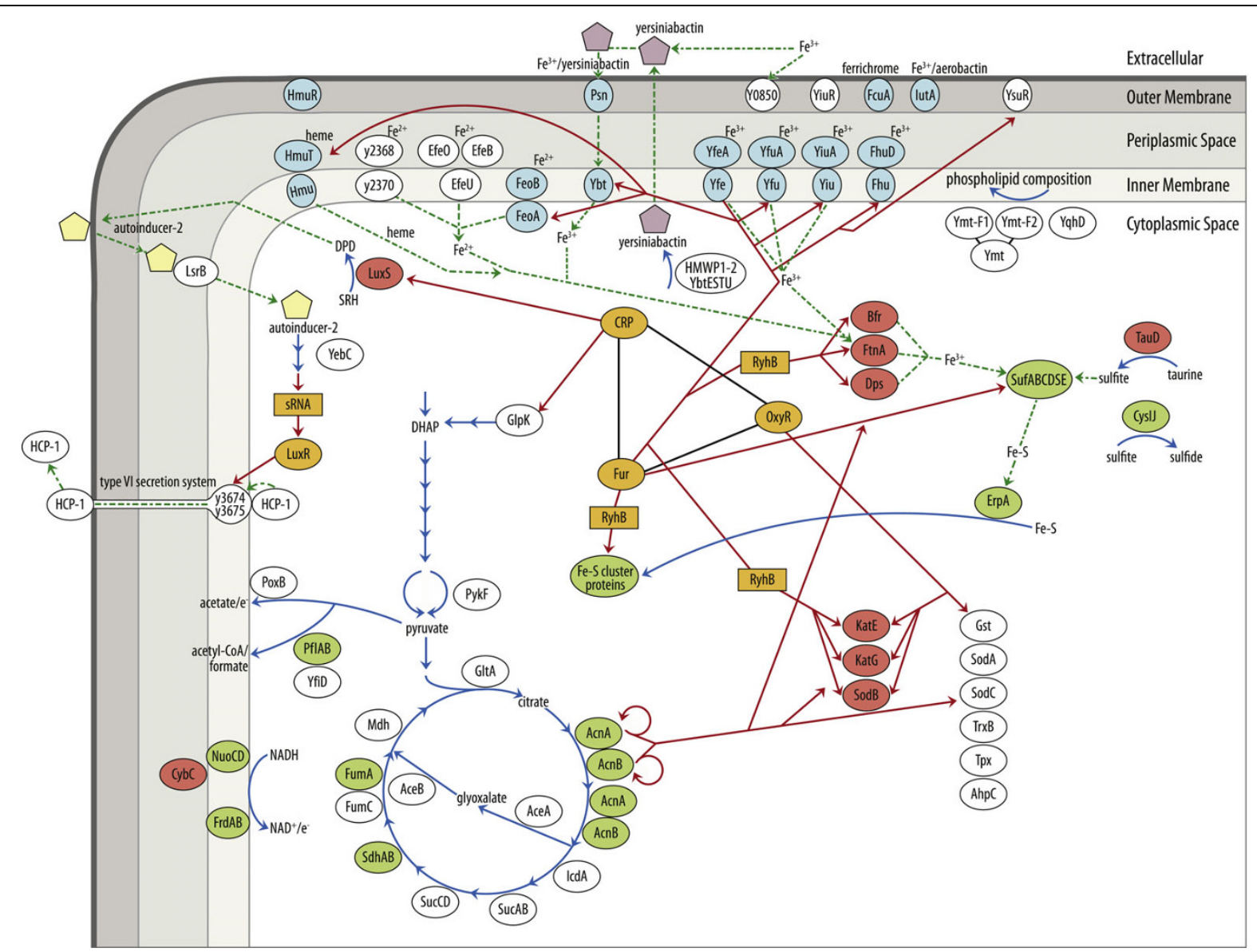

Figure $\mathbf{5}$ Iron homeostasis in $Y$. pestis. The center of the schematic depicts a network of regulators (orange color), known or potentially involved in iron homeostasis. Details are provided in the text. CRP (carbon metabolism); OxyR (oxidative stress); Fur and small RNAs like RyhB (iron homeostasis). Red lines/arrows show which genes (or mRNAs) are controlled by these regulators. Additional arrows symbolize enzymatic reactions (blue line) or small molecule transport processes (dotted green line). The lower/left side of the schematic depicts components of the energy metabolism. It includes glycolytic steps from dihydroxyacetone phosphate (DHAP) to pyruvate, the TCA/glyoxalate bypass cycle and on the left side alternative pyruvate metabolism branches generating acetate or acetyl-CoA. Subunits of electron transport systems (NuoCD, FrdAB and $(\mathrm{ybC}$ ) are also displayed. The top/left side of the schematic pertains to quorum sensing. LuxS converts S-ribosylhomocysteine (SRH) to 4,5dihydroxy-2,3-pentanedione (DPD) which is a precursor of autoinducer-2 (yellow pentagon). In E. coli, the autoinducer-2 is exported and imported via periplasmic LsrB into different cells followed by activation of LuxR via small RNA regulators. The precise functional role of YebC in quorum sensing is not known. LuxR influences the expression of virulence factors in pathogenic E. coli strains. The role of LuxR in the regulation of the type $\mathrm{VI}$ secretion system is speculative, but both iron starvation [73] and the T6SS [74] have been linked to quorum sensing in other organisms. In the upper part of the schematic, iron transporter subunits are placed according their predicted or known subcellular localizations. Transporters with a blue color background are known to be functional in Y. pestis. On the center/right side, iron storage proteins, the Suf Fe-S cluster assembly system and putative sulfur-mobilizing enzymes (TauD and CysIJ) are displayed. The bottom/right part of the schematic features oxidative stress response proteins. Finally, the top/right part of the schematic displays the flea survival factor Ymt and its fragments, as well as the protein YqhD. These proteins may be implicated in the enzymatic modifications of IM phospholipids. Proteins with a red and green background harbor iron/heme and Fe-S cluster cofactors, respectively.

Y3676 \#86 (Figure 1) and Y3674 \#110 (Figure 3) were not at all detected in $Y$. pestis protein profiles at $37^{\circ} \mathrm{C}$. The T6SS is temperature-regulated. The flea survival factor $\mathrm{Ymt}_{\# 15}$ (Figure 4) was moderately increased in ironstarved cells at $26^{\circ} \mathrm{C}$. It was one of the most abundant proteins in cells grown at $26^{\circ} \mathrm{C} . \mathrm{N}$ - and C-terminal fragments of $\mathrm{Ymt}$, each $c a .30 \mathrm{kDa}$ in size and with a single cleavage site between $\mathrm{V}_{300}$ and $\mathrm{I}_{304}\left(\mathrm{Ymt}_{\# 16}\right.$ and
$\mathrm{Ymt}_{\# 17}$, respectively; Figure 4), were also increased under $-\mathrm{Fe} v s$. $+\mathrm{Fe}$ conditions. There is no evidence for a connection between the functional roles of Ymt or the T6SS and the iron starvation response.

Periplasmic subunits of $\mathrm{ABC}$ transporters for amino acids, sugars and phosphate, various diffusion porins of the OM allowing passage of nutrients into the periplasm, and various amino acid tRNA-synthetases and enzymes 
implicated in amino acid biosynthesis were significantly increased in abundance in iron-replete cells. These observations were consistent with the notion that $Y$. pestis cells grown to stationary phase under $+\mathrm{Fe}$ conditions were depleted of various nutrients and induced the expression of high affinity transport systems for their import into the cell. Examples were the phosphate-specific OM porin $\mathrm{PhoE}_{\# 109}$ (Figure 3) and the periplasmic maltose-binding protein $\mathrm{MalE}_{\# 53}$ (Figure 1), each of which was much more abundant under $+\mathrm{Fe} v s$. $-\mathrm{Fe}$ conditions.

\section{Discussion}

\section{Regulation of iron homeostasis}

Fur in $Y$. pestis, as in many other Gram-negative bacteria, is a central transcriptional regulator responding to the cellular iron status $[20,50]$, as indicated in the schematic of Figure 5. Many iron uptake systems are transcriptionally repressed during iron-replete growth conditions to reduce accumulation of intracellular iron. Evidence has emerged that small RNA regulators are implicated in bacterial stress responses [22]. These small RNAs act by base-pairing with specific mRNAs whose translation they stimulate or inhibit in the presence of a unique protein, the RNA chaperone Hfq. A small RNA of 90 nucleotides determined to regulate genes involved in iron homeostasis in E. coli [23] and Pseudomonas aeruginosa [24] was termed RyhB. It is negatively regulated by Fur and was shown to down-regulate the translation of many of the same iron-dependent enzymes we detected as decreased in iron-starved $Y$. pestis cells (SdhA, AcnA, FumA, FrdA, SodB, KatE and KatY) [23]. We hypothesize that one or both of the conserved $Y$. pestis homologs of RyhB [22] co-regulate $Y$. pestis iron homeostasis and selectively decrease translation of mRNAs whose protein products depend on or store iron, as illustrated in Figure 5. Such a mechanism may restrict the use of scarce intracellular iron to processes pivotal to bacterial survival. Some of the encoding genes (e.g. ftnA, katE and $\operatorname{sod} B$ ) may also be positively controlled by Fur as suggested by Yang et al. [35]. Gel shift assays revealed binding of recombinant Fur to promoter regions upstream of the genes $f t n A$ and $k a t E$ [20].

Several of the enzymes decreased in abundance in iron-deficient $Y$. pestis harbor Fe-S clusters. Expression of the respective genes did not appear to be altered under conditions sequestering or depleting iron in $Y$. pestis according to two DNA microarray studies $[33,35]$ and suggests post-transcriptional mechanisms. The involvement of RyhB in controlling the abundances of proteins with iron cofactors when cells are iron-deficient needs to be verified. Since our data were derived from proteomic comparisons of $Y$. pestis cells harvested at different cell densities $\left(\mathrm{OD}_{600} \mathrm{~S}\right.$ of $\sim 2.0$ for stationary phase cells $v s$. $\mathrm{OD}_{600} \mathrm{~S}$ of $\sim 0.8$ for growth arrested, iron- starved cells), the argument can be made that population density differences account for some of the protein abundance changes. Unpublished data (Pieper, R.) and a previous study analyzing the $Y$. pestis periplasmic proteome in the context of two growth phases [39] allow us to largely refute this notion. Among the proteins with iron or Fe-S cofactors, only PflB and KatE were increased in stationary $v s$. exponential phase proteomic profiles with ratios comparable to those observed in iron-rich vs. iron-starved cells. FtnA and Bfr are iron storage proteins and, via regulation by $\mathrm{Ryh} B$, were reported to be quantitatively decreased when iron supplies are limited in E. coli [23]. Our data on the FtnA and Bfr orthologs of $Y$. pestis were not consistent with the results of the aforementioned studies, nor with two $Y$. pestis transcriptional profiling studies where increased bfr expression and, in one case, decreased $f t n A$ expression were reported for iron-limiting growth environments [33,35].

Post-transcriptional regulatory functions in iron-deficient cells have also been attributed to aconitases. In fact, eukaryotic AcnA has been termed iron-responsive protein 1 (IRP-1) [60]. Apo-enzyme versions of E. coli aconitases stabilize their cognate mRNAs and influence the expression of $\operatorname{sodA}$. AcnA enhanced $\operatorname{sodA}$ transcript stability and was induced by iron starvation and oxidative stress in E. coli $[61,62]$. These findings could not be easily reconciled with our data onAcnA and $A c n B$ abundance changes in $Y$. pestis. AcnA and AcnB were decreased in abundance, as were the combined aconitase activities, in iron-depleted cells. SodA abundance was not significantly affected by either growth phase [39] or iron depletion. The response of $Y$. pestis to iron starvation and cellular stress resulting from the loss of this metal ion seems to implicate a network of regulators, as presented in Figure 5. Indeed, functional relationships between Fur and OxyR [32], Fur and CRP [31] and Fur and apo-aconitases [62] were previously reported for E. coli.

\section{Iron starvation stress responses}

Numerous E. coli genes encoding oxidative stress response proteins are co-regulated by SoxR, Fur and OxyR according to information in the EcoCyc database. The OxyR $\mathrm{H}_{2} \mathrm{O}_{2}$-response system restored Fur repression in iron-replete media during oxidative stress in E. coli [32], a mechanism that we think is also relevant in $Y$. pestis. Strong abundance decreases in ironstarved $Y$. pestis cells were observed for three irondependent proteins, SodB, KatE and KatY. The three enzymes detoxify peroxides and radicals formed during oxidative stress. Proteins with similar functions but cofactors other than iron (e.g. SodA and AhpC) were not markedly changed in abundance. Functional assays supported such proteomic data; SOD activities in 
iron-depleted cells dropped markedly less than catalase activities. In conclusion, our data strongly support the notion that $Y$. pestis adapts its repertoire of oxidative stress response enzymes by limiting the expression of iron cofactor-dependent enzymes, when iron is in short supply. The coordination of bacterial responses to iron limitation and the defence against oxidative stress was proposed earlier [63].

\section{Iron acquisition systems}

All $Y$. pestis biovars have several proven iron acquisition systems, and transcriptional control by Fur has been demonstrated $[18,64]$. The genes and operons for putative iron transporters (e.g. Ysu, Fit, Fhu, Iuc, Has) also feature conserved 19-nt Fur-binding sites to which recombinant Fur binds [20]. Our data indicated that none of the abovementioned iron transporters were expressed at levels similar to those observed for subunits of proven iron transport systems (Ybt, Yfe, Yfu, Yiu and $\mathrm{Hmu}$ ) under iron-deficient conditions. Two microarray studies, however, reported increased transcript abundances for many of the putative iron transporters when iron was complexed with dipyridyl [35] or sequestered by iron-binding proteins in blood plasma [33]. 2D gel analysis has known limitations pertaining to protein detection sensitivity and the resolution of hydrophobic IM-localized proteins, e.g. many nutrient transporters. Except Ysu subunits, unproven iron transporters were also not profiled employing a peptide-based LC-MS/MS analysis approach with $Y$. pestis lysates $[47,65]$. These lysates were derived from iron-replete growth conditions. Only functional iron transporters are presented in the schematic of Figure 5 and appear to follow a hierarchy of importance in the order of Ybt, Yfe (each important for virulence in a bubonic plague model), Yfu and Yiu [15]. The delivery of $\mathrm{Fe}^{3+}$ or $\mathrm{Fe}^{2+}$ from the extracellular milieu to periplasmic binding proteins of the $A B C$ transporters Yfe, Yfu and Yiu is unclear, although a YiuR surface receptor was expressed according to our data. The Hmu transporter acquires heme from blood plasma proteins such as myoglobin, hemoglobin and hemopexin [16]. Three $\mathrm{Fe}^{2+}$ transport systems (EfeUOB, Y2368-Y2370 and FeoAB, Figure 5) were shown to be functional in either $Y$. pestis [17] or other bacteria [66-68]. We identified the subunits EfeO and Y2368 as periplasmic proteins, and their abundance increases in iron-deficient cells appeared to be moderately temperature-dependent. There is no evidence to date for their regulation by Fur. FeoB was recently identified in $Y$. pestis membrane proteome surveys $[47,65]$. A protein highly abundant in membrane fractions of iron-depleted $Y$. pestis cells but not characterized in the context of iron transport was the orphan TonB-dependent OM receptor Y0850. The protein is a candidate for Fur regulation and the contribution to iron uptake, but its exact function remains to be elucidated. A conserved Fur box upstream of the gene and sequence similarity of Y0850 to Bordetella bronchiseptica BfrA and Campylobacter coli CfrA $[69,70]$ were established. Our proteomic surveys did not support the activation of specific iron uptake pathways at only one of the physiologically relevant temperatures. Based on multivariate transcriptional profiling data for $Y$. pestis $\left(28^{\circ} \mathrm{C} v s .37^{\circ} \mathrm{C}\right.$, iron-supplemented cell growth $v s$. iron sequestration in plasma), Carniel et al. [33] suggested that the Ybt system and the TonB protein are of particular importance for iron acquisition at $37^{\circ} \mathrm{C}$.

\section{Fe-S cluster biosynthesis and energy metabolism in iron-starved $Y$. pestis}

Growth of iron-depleted $Y$. pestis cells was arrested at an $\mathrm{OD}_{600}$ of $\sim 0.8$, indicative of the inability of iron-dependent enzymes to perform essential metabolic functions. In addition to the already discussed impact of iron depletion on oxidative stress response enzymes and aconitases, we explored how Fe-S cluster assembly systems and other energy metabolism enzymes were affected. Ironsulfur clusters are critical to the function of many redox enzymes in bacteria [27]. Incorporation of $\mathrm{Fe}-\mathrm{S}$ into proteins requires $\mathrm{Fe}-\mathrm{S}$ cluster assembly systems, which were named Suf and Isc in E. coli. Our data showed that SufA, SufB, SufC and SufS, four of the six subunits of the Suf complex, were more abundant under iron starvation conditions. Regulation of the $Y$. pestis suf operon by Fur and a functional Fur-binding site were reported previously [20]. The cysteine desulfurase subunits of the Suf and Isc systems (SufS and CsdA, respectively) were quantitatively changed in opposite directions $(-\mathrm{Fe} v s$. $+\mathrm{Fe})$, suggesting that Suf functionally replaces Isc at the onset of iron starvation in $Y$. pestis. Mobilization of sulfur from cysteine appears to be catalyzed by SufS in E. coli [71]. The increased abundance of TauD, an enzyme that mobilizes sulfite from taurine, in iron-depleted $Y$. pestis cells was intriguing. TauD is a dioxygenase, harbors a $\mathrm{Fe}^{2+}$ cofactor and was reported to be induced under sulfate starvation conditions in E. coli [72]. We speculate that TauD plays an accessory role in sulphur mobilization for Fe-S cluster assembly via the Suf pathway. Furthermore, the $Y$. pestis ortholog of a recently discovered $\mathrm{Fe}-\mathrm{S}$ cluster protein ErpA was also increased under iron-limiting conditions. Since ErpA was proposed to transfer Fe-S clusters to apo-enzymes [56], we hypothesize that $Y$. pestis ErpA may perform such activities cooperatively with the Suf system. Transcriptional data on $\operatorname{erp} A$ and tauD expression changes for $-\mathrm{Fe} v s$. $+\mathrm{Fe}$ growth conditions are not available. Mammalian hosts starve $Y$. pestis of iron and, therefore, the Suf complex constitutes a good target for inhibitory drug design. 
Enzymes with Fe-S clusters in their catalytic cores, many of them in the TCA cycle, are also displayed in Figure 5. Although in different ratios, subunits of such enzyme complexes (e.g. FumA, SdhA, FrdA and CysJ) were invariably decreased in abundance in iron-starved $Y$. pestis cells. Most of these quantitative decreases appear to be unrelated to population density differences, because they were not observed in cells cultured to stationary $v s$. exponential phase in iron-replete PMH2 medium(Pieper, R., unpublished data). A decreased pyruvate metabolism rate should be the consequence of the loss of $\mathrm{Fe}-\mathrm{S}$ cluster enzyme activities in the TCA cycle and may be followed by reduced production of ATP and NADPH reducing equivalents in the electron transport chain. Furthermore, a decreased turnover of citrate may lead to its accumulation in the cytoplasm, which could chelate iron and exacerbate iron starvation [30]. A highly interesting observation was the dramatic abundance and activity increase of PoxB in iron-starved $Y$. pestis cells, both at $26^{\circ} \mathrm{C}$ and $37^{\circ} \mathrm{C}$. PoxB activity increases were independent of $Y$. pestis cell densities during growth in chemically defined media. pox $B$ expression was reported to be moderately enhanced in $Y$. pestis cells grown in human plasma vs. LB media [33]. We suggest that the metabolism of pyruvate via the PoxB route compensates for reduced activities of $\mathrm{Fe}-\mathrm{S}$ cluster enzymes in the TCA cycle. The pathway catalyzed by PoxB is iron-independent. The E. coli ortholog, a thiamin/ flavin-dependent enzyme activated by binding to IM phospholipids, was shown to feed electrons directly from the cytosol to the respiratory chain [52]. To our knowledge, this is the first report linking enhanced PoxB activities in bacteria specifically to iron starvation. PoxB is a potential drug target in the context of intracellular pathogens surviving in environments where iron is sequestered.

\section{Conclusions}

Proteomic surveys of $Y$. pestis subcellular fractions grown under iron-replete $v s$. iron-starved conditions supported the physiological importance of the iron acquisition systems Ybt, Yfe, Yfu, Yiu and Hmu. An uncharacterized TonB-dependent OM receptor, Y0850, was also highly abundant in iron-depleted cells, appeared to be Fur-regulated and may participate in iron uptake. Numerous enzymes harboring iron and Fe$\mathrm{S}$ cluster cofactors were significantly decreased in abundance in iron-starved cells, suggesting a regulatory process shifting the metabolism of $Y$. pestis to ironindependent pathways when the supply of this metal ion is limited. Small Fur-regulated RNAs termed RyhB in $E$. coli may be involved in this process. Finally, this study revealed biochemical pathways likely essential for the iron starvation response in $Y$. pestis. Examples are the energy metabolism via the pyruvate oxidase route and Fe-S cluster assembly mediated by the Suf system.
Additional file 1: Yersinia pestis growth curves in $\mathrm{PMH} 2$ medium. Growth curves $\left(\mathrm{OD}_{600}\right)$ are displayed in graphical form for $Y$. pestis KIM6+ cell cultures in iron rich and iron-depleted media, at $26^{\circ} \mathrm{C}$ and at $37^{\circ} \mathrm{C}$. Click here for file

[http://www.biomedcentral.com/content/supplementary/1471-2180-1030-S1.DOC ]

Additional file 2: Comprehensive list of differentially displayed Yersinia pestis proteins comparing iron-replete and iron starvation conditions. A variety of qualitative and quantitative data are provided for differentially displayed proteins derived from + Fe vs. -Fe growth conditions, from cell cultures at $26^{\circ} \mathrm{C}$ and at $37^{\circ} \mathrm{C}$.

Click here for file

[http://www.biomedcentral.com/content/supplementary/1471-2180-1030-S2.XLS ]

Additional file 3: Comprehensive list of MS and $\mathrm{MS}^{2}$ data for $Y$. pestis KIM6+ proteins. For all proteins listed in the Tables 1, 2 and 3 and in the Additional File 2, MS and $\mathrm{MS}^{2}$ data were parsed from MALDITOFTOF and LC-nESI-LC-MS/MS datasets.

Click here for file

[http://www.biomedcentral.com/content/supplementary/1471-2180-1030-S3.XLS]

\section{Abbreviations}

2D: 2-dimensional gel electrophoresis; CBB: Coomassie Brilliant Blue G250; Fe-S: iron-sulfur; IM: inner membrane; usb-MBR: urea/thiourea/ amidosulfobetaine-14-extracted membrane; IPG: immobilized pH gradient; OM: outer membrane; SOD: superoxide dismutase; T3SS: type III secretion system; T6SS: type VI secretion system; TMD: transmembrane domain; $V_{\mathrm{S}}$ : spot volume.

\section{Acknowledgements}

This work was performed under the Pathogen Functional Genomics Resource Center contract (contract No. N01-Al15447), funded by the National Institute of Allergy and Infectious Diseases, National Institutes of Health. We thank Jasmine Pollard for the graphic presented in Figure 4, Christine Bunai for the development of the mass spectrometry analysis platform and John Braisted for advice on statistical data analysis methods.

\section{Author details}

1J. Craig Venter Institute, 9704 Medical Center Drive, Rockville, MD 20850, USA. ${ }^{2}$ Department of Microbiology, Immunology and Molecular Genetics, University of Kentucky, Lexington, KY 40536, USA.

\section{Authors' contributions}

RP: primary role in designing the study, analyzing and interpreting the data, performing the enzyme assays, writing the article; STH: quantitative and bioinformatic data analysis, database queries, generation of Figures and Tables for the article; PPP: sample preparation, 2D gel experiments and proof-reading; DJC: acquisition of the LC-MS/MS data; HA: acquisition of the MALDI-MS data; RDF: generated the framework for the performance of this study; RDP: major role in the design and initial experiments of the study, biological interpretation of the data, writing parts of the article and its review; SNP: major role in the biological data interpretation and the review of the article.

\section{Competing interests}

The authors declare that they have no competing interests.

Received: 15 January 2010

Accepted: 29 January 2010 Published: 29 January 2010

\section{References}

1. Brubaker RR, Sussman M: Yersinia pestis. Molecular Medical Microbiology London, UK: Academic Press 2002, 3:2033-2058.

2. Deng W, Burland V, Plunkett G, Boutin A, Mayhew GF, Liss P, Perna NT, Rose DJ, Mau B, Zhou S, et al: Genome sequence of Yersinia pestis KIM. J Bacteriol 2002, 184(16):4601-4611. 
3. Hu P, Elliott J, McCready P, Skowronski E, Garnes J, Kobayashi A Brubaker RR, Garcia E: Structural organization of virulence-associated plasmids of Yersinia pestis. J Bacteriol 1998, 180(19):5192-5202.

4. Lindler LE, Plano GV, Burland V, Mayhew GF, Blattner FR: Complete DNA sequence and detailed analysis of the Yersinia pestis KIM5 plasmid encoding murine toxin and capsular antigen. Infect Immun 1998, 66(12):5731-5742.

5. Hinnebusch BJ: The evolution of flea-borne transmission of Yersinia pestis. Yersinia Molecular and Cellular Biology Norfolk, U.K.: Horizon BioscienceCarniel EaH BJ 2004, 49-73.

6. Perry RD, Fetherston JD: Yersinia pestis-etiologic agent of plague. Clin Microbiol Rev 1997, 10(1):35-66.

7. Jarrett CO, Deak E, Isherwood KE, Oyston PC, Fischer ER, Whitney AR, Kobayashi SD, DeLeo FR, Hinnebusch BJ: Transmission of Yersinia pestis from an infectious biofilm in the flea vector. J Infect Dis 2004, 190(4):783-792.

8. Perry RD, Bobrov AG, Kirillina O, Jones HA, Pedersen L, Abney J, Fetherston JD: Temperature regulation of the hemin storage ( $\mathrm{Hms}+$ ) phenotype of Yersinia pestis is posttranscriptional. J Bacterio/ 2004, 186(6):1638-1647.

9. Schaible UE, Kaufmann SH: Iron and microbial infection. Nat Rev Microbiol 2004, 2(12):946-953.

10. Bearden SW, Fetherston JD, Perry RD: Genetic organization of the yersiniabactin biosynthetic region and construction of avirulent mutants in Yersinia pestis. Infect Immun 1997, 65(5):1659-1668.

11. Fetherston JD, Bertolino VJ, Perry RD: YbtP and YbtQ: two ABC transporters required for iron uptake in Yersinia pestis. Mol Microbiol 1999, 32(2):289-299.

12. Fetherston JD, Lillard JW Jr, Perry RD: Analysis of the pesticin receptor from Yersinia pestis: role in iron-deficient growth and possible regulation by its siderophore. J Bacteriol 1995, 177(7):1824-1833.

13. Bearden SW, Perry RD: The Yfe system of Yersinia pestis transports iron and manganese and is required for full virulence of plague. $\mathrm{Mol}$ Microbiol 1999, 32(2):403-414

14. Gong S, Bearden SW, Geoffroy VA, Fetherston JD, Perry RD: Characterization of the Yersinia pestis Yfu $A B C$ inorganic iron transport system. Infect Immun 2001, 69(5):2829-2837.

15. Kirillina O, Bobrov AG, Fetherston JD, Perry RD: Hierarchy of iron uptake systems: Yfu and Yiu are functional in Yersinia pestis. Infect Immun 2006, 74(11):6171-6178.

16. Thompson JM, Jones HA, Perry RD: Molecular characterization of the hemin uptake locus ( $\mathrm{hmu}$ ) from Yersinia pestis and analysis of hmu mutants for hemin and hemoprotein utilization. Infect Immun 1999, 67(8):3879-3892.

17. Perry RD, Mier I Jr, Fetherston JD: Roles of the Yfe and Feo transporters of Yersinia pestis in iron uptake and intracellular growth. Biometals 2007, 20(3-4):699-703.

18. Perry RD, Fetherston JD: Iron and Heme Uptake Systems. Yersinia Molecular and Cellular Biology Norfolk, U.K.: Horizon BioscienceCarniel EaH BJ 2004, 257-283.

19. Hantke K: Iron and metal regulation in bacteria. Curr Opin Microbiol 2001, 4(2):172-177.

20. Gao H, Zhou D, Li Y, Guo Z, Han Y, Song Y, Zhai J, Du Z, Wang X, Lu J, et al: The iron-responsive Fur regulon in Yersinia pestis. J Bacteriol 2008, 190(8):3063-3075.

21. de Lorenzo V, Perez-Martín J, Escolar L, Pesole G, Bertoni G: Mode of binding of the Fur protein to target DNA: negative regulation of ironcontrolled gene expression. Washington D.C.: ASM Press 2004.

22. Gottesman S, McCullen CA, Guillier M, Vanderpool CK, Majdalani N, Benhammou J, Thompson KM, FitzGerald PC, Sowa NA, FitzGerald DJ: Small RNA regulators and the bacterial response to stress. Cold Spring Harb Symp Quant Biol 2006, 71:1-11.

23. Masse $E$, Gottesman S: A small RNA regulates the expression of genes involved in iron metabolism in Escherichia coli. Proc Natl Acad Sci USA 2002, 99(7):4620-4625.

24. Wilderman PJ, Sowa NA, FitzGerald DJ, FitzGerald PC, Gottesman S, Ochsner UA, Vasil ML: Identification of tandem duplicate regulatory small RNAs in Pseudomonas aeruginosa involved in iron homeostasis. Proc Natl Acad Sci USA 2004, 101(26):9792-9797.

25. Kadner RJ: Regulation by iron: RNA rules the rust. J Bacteriol 2005, 187(20):6870-6873.
26. Masse $E$, Salvail H, Desnoyers G, Arguin M: Small RNAs controlling iron metabolism. Curr Opin Microbiol 2007, 10(2):140-145.

27. Kiley PJ, Beinert $\mathrm{H}$ : The role of Fe-S proteins in sensing and regulation in bacteria. Curr Opin Microbiol 2003, 6(2):181-185.

28. Cheng W, Ma E, Zhao Z, Rothery RA, Weiner JH: The iron-sulfur clusters in Escherichia coli succinate dehydrogenase direct electron flow. J Biol Chem 2006, 281(37):27662-27668.

29. Flint DH, Emptage MH, Guest JR: Fumarase a from Escherichia coli: purification and characterization as an iron-sulfur cluster containing enzyme. Biochemistry 1992, 31(42):10331-10337.

30. Varghese S, Tang Y, Imlay JA: Contrasting sensitivities of Escherichia coli aconitases A and B to oxidation and iron depletion. J Bacteriol 2003, 185(1):221-230.

31. Zhang Z, Gosset G, Barabote R, Gonzalez CS, Cuevas WA, Saier MH Jr: Functional interactions between the carbon and iron utilization regulators, Crp and Fur, in Escherichia coli. J Bacteriol 2005, 187(3):980-990.

32. Varghese $S$, Wu A, Park S, Imlay KR, Imlay JA: Submicromolar hydrogen peroxide disrupts the ability of Fur protein to control free-iron levels in Escherichia coli. Mol Microbiol 2007, 64(3):822-830.

33. Chauvaux S, Rosso ML, Frangeul L, Lacroix C, Labarre L, Schiavo A Marceau M, Dillies MA, Foulon J, Coppee JY, et al: Transcriptome analysis of Yersinia pestis in human plasma: an approach for discovering bacterial genes involved in septicaemic plague. Microbiology 2007, 153(Pt 9):3112-3124.

34. Han Y, Qiu J, Guo Z, Gao H, Song Y, Zhou D, Yang R: Comparative transcriptomics in Yersinia pestis: a global view of environmenta modulation of gene expression. BMC Microbiol 2007, 7:96.

35. Zhou D, Qin L, Han Y, Qiu J, Chen Z, Li B, Song Y, Wang J, Guo Z, Zhai J, et al: Global analysis of iron assimilation and fur regulation in Yersinia pestis. FEMS Microbiol Lett 2006, 258(1):9-17.

36. Fetherston JD, Perry RD: The pigmentation locus of Yersinia pestis KIM6 + is flanked by an insertion sequence and includes the structural genes for pesticin sensitivity and HMWP2. Mol Microbiol 1994, 13(4):697-708

37. Lillard JW Jr, Bearden SW, Fetherston JD, Perry RD: The haemin storage (Hms+) phenotype of Yersinia pestis is not essential for the pathogenesis of bubonic plague in mammals. Microbiology 1999, 145(Pt 1):197-209.

38. Lucier TS, Fetherston JD, Brubaker RR, Perry RD: Iron uptake and ironrepressible polypeptides in Yersinia pestis. Infect Immun 1996, 64(8):3023-3031.

39. Pieper R, Huang ST, Clark DJ, Robinson JM, Parmar PP, Alami H, Bunai CL, Perry RD, Fleischmann RD, Peterson SN: Characterizing the dynamic nature of the Yersinia pestis periplasmic proteome in response to nutrient exhaustion and temperature change. Proteomics 2008, 8(7):1442-1458.

40. Chang YY, Cronan JE Jr: Mapping nonselectable genes of Escherichia coli by using transposon Tn10: location of a gene affecting pyruvate oxidase. J Bacteriol 1982, 151(3):1279-1289.

41. Rose IA, O'Connell EL: Mechanism of aconitase action. I. The hydrogen transfer reaction. J Biol Chem 1967, 242(8):1870-1879.

42. Johansson LH, Borg LA: A spectrophotometric method for determination of catalase activity in small tissue samples. Anal Biochem 1988, 174(1):331-336.

43. Peskin AV, Winterbourn CC: A microtiter plate assay for superoxide dismutase using a water-soluble tetrazolium salt (WST-1). Clin Chim Acta 2000, 293(1-2):157-166

44. Pieper R, Huang ST, Robinson JM, Clark DJ, Alami H, Parmar PP, Perry RD, Fleischmann RD, Peterson SN: Temperature and growth phase influence the outer-membrane proteome and the expression of a type $\mathrm{VI}$ secretion system in Yersinia pestis. Microbiology 2009, 155(Pt 2):498-512.

45. Gatlin CL, Pieper R, Huang ST, Mongodin E, Gebregeorgis E, Parmar PP, Clark DJ, Alami H, Papazisi L, Fleischmann RD, et al: Proteomic profiling of cell envelope-associated proteins from Staphylococcus aureus. Proteomics 2006, 6(5):1530-1549.

46. Bagos PG, Liakopoulos TD, Spyropoulos IC, Hamodrakas SJ: PRED-TMBB: a web server for predicting the topology of beta-barrel outer membrane proteins. Nucleic Acids Res 2004, , 32 Web Server: W400-404.

47. Pieper R, Huang ST, Clark DJ, Robinson JM, Alami H, Parmar PP, Suh MJ, Kuntumalla $S$, Bunai $C L$, Perry $R D$, et al: Integral and peripheral association 
of proteins and protein complexes with Yersinia pestis inner and outer membranes. Proteome Sci 2009, 7:5.

48. Suh M-J, Alami H, Clark DJ, Parmar PP, Robinson JM, Huang S-T, Fleischmann RD, Peterson SN, Pieper R: Widespread Occurrence of NonEnzymatic Deamidations of Asparagine Residues in Yersinia pestis Proteins Resulting from Alkaline pH Membrane Extraction Conditions. Open Proteomics J 2008, 1:106-115.

49. Perry RD, Abney J, Mier I Jr, Lee Y, Bearden SW, Fetherston JD: Regulation of the Yersinia pestis Yfe and Ybt iron transport systems. Adv Exp Med Biol 2003, 529:275-283.

50. Staggs TM, Perry RD: Fur regulation in Yersinia species. Mol Microbiol 1992 6(17):2507-2516

51. van Helden J: Regulatory sequence analysis tools. Nucleic Acids Res 2003, 31(13):3593-3596.

52. Neumann P, Weidner A, Pech A, Stubbs MT, Tittmann K: Structural basis for membrane binding and catalytic activation of the peripheral membrane enzyme pyruvate oxidase from Escherichia coli. Proc Natl Acad Sci USA 2008, 105(45):17390-17395.

53. Belevich G, Euro L, Wikstrom M, Verkhovskaya M: Role of the conserved arginine 274 and histidine 224 and 228 residues in the NuoCD subunit of complex I from Escherichia coli. Biochemistry 2007, 46(2):526-533.

54. Imlay JA: Pathways of oxidative damage. Annu Rev Microbiol 2003, 57:395-418.

55. Outten FW, Djaman O, Storz G: A suf operon requirement for Fe-S cluster assembly during iron starvation in Escherichia coli. Mol Microbiol 2004, 52(3):861-872.

56. Loiseau L, Gerez C, Bekker M, Ollagnier-de Choudens S, Py B, Sanakis Y, Teixeira de Mattos J, Fontecave M, Barras F: ErpA, an iron sulfur (Fe S) protein of the A-type essential for respiratory metabolism in Escherichia coli. Proc Natl Acad Sci USA 2007, 104(34):13626-13631.

57. Vendeville A, Winzer K, Heurlier K, Tang CM, Hardie KR: Making 'sense' of metabolism: autoinducer-2, LuxS and pathogenic bacteria. Nat Rev Microbiol 2005, 3(5):383-396.

58. Liang H, Li L, Dong Z, Surette MG, Duan K: The YebC family protein PA0964 negatively regulates the Pseudomonas aeruginosa quinolone signal system and pyocyanin production. J Bacteriol 2008, 190(18):6217-6227.

59. Bobrov AG, Bearden SW, Fetherston JD, Khweek AA, Parrish KD, Perry RD: Functional quorum sensing systems affect biofilm formation and protein expression in Yersinia pestis. Adv Exp Med Biol 2007, 603:178-191.

60. Cairo G, Pietrangelo A: Iron regulatory proteins in pathobiology. Biochem J 2000, 352(Pt 2):241-250.

61. Tang Y, Guest JR: Direct evidence for mRNA binding and posttranscriptional regulation by Escherichia coli aconitases. Microbiology 1999, 145(Pt 11):3069-3079

62. Tang Y, Quail MA, Artymiuk PJ, Guest JR, Green J: Escherichia coli aconitases and oxidative stress: post-transcriptional regulation of sodA expression. Microbiology 2002, 148(Pt 4):1027-1037.

63. Touati D: Iron and oxidative stress in bacteria. Arch Biochem Biophys 2000, 373(1):1-6.

64. Zhou D, Han Y, Yang R: Molecular and physiological insights into plague transmission, virulence and etiology. Microbes Infect 2006, 8(1):273-284

65. Hixson KK, Adkins JN, Baker SE, Moore RJ, Chromy BA, Smith RD, McCutchen-Maloney SL, Lipton MS: Biomarker candidate identification in Yersinia pestis using organism-wide semiquantitative proteomics. J Proteome Res 2006, 5(11):3008-3017.

66. Cao J, Woodhall MR, Alvarez J, Cartron ML, Andrews SC: EfeUOB (YcdNOB) is a tripartite, acid-induced and CpxAR-regulated, low-pH Fe2+ transporter that is cryptic in Escherichia coli K-12 but functional in E. coli O157:H7. Mol Microbiol 2007, 65(4):857-875.

67. Dubbels BL, DiSpirito AA, Morton JD, Semrau JD, Neto JN, Bazylinski DA: Evidence for a copper-dependent iron transport system in the marine, magnetotactic bacterium strain MV-1. Microbiology 2004, 150(Pt 9):2931-2945.

68. Grosse C, Scherer J, Koch D, Otto M, Taudte N, Grass G: A new ferrous iron-uptake transporter, EfeU (YcdN), from Escherichia coli. Mol Microbiol 2006, 62(1):120-131.

69. Beall B, Hoenes T: An iron-regulated outer-membrane protein specific to Bordetella bronchiseptica and homologous to ferric siderophore receptors. Microbiology 1997, 143(Pt 1):135-145.
70. Guerry P, Perez-Casal J, Yao R, McVeigh A, Trust TJ: A genetic locus involved in iron utilization unique to some Campylobacter strains. J Bacteriol 1997, 179(12):3997-4002.

71. Layer G, Gaddam SA, Ayala-Castro CN, Ollagnier-de Choudens S, Lascoux D, Fontecave M, Outten FW: SufE transfers sulfur from SufS to SufB for ironsulfur cluster assembly. J Biol Chem 2007, 282(18):13342-13350.

72. Ploeg van der JR, Weiss MA, Saller E, Nashimoto H, Saito N, Kertesz MA, Leisinger T: Identification of sulfate starvation-regulated genes in Escherichia coli: a gene cluster involved in the utilization of taurine as a sulfur source. J Bacteriol 1996, 178(18):5438-5446.

73. Oglesby AG, Farrow JM, Lee JH, Tomaras AP, Greenberg EP, Pesci EC, Vasil ML: The influence of iron on Pseudomonas aeruginosa physiology: a regulatory link between iron and quorum sensing. J Biol Chem 2008, 283(23):15558-15567.

74. Liu H, Coulthurst SJ, Pritchard L, Hedley PE, Ravensdale M, Humphris S, Burr T, Takle G, Brurberg MB, Birch PR, et al: Quorum sensing coordinates brute force and stealth modes of infection in the plant pathogen Pectobacterium atrosepticum. PLoS Pathog 2008, 4(6):e1000093.

doi:10.1186/1471-2180-10-30

Cite this article as: Pieper et al:: Proteomic analysis of iron acquisition, metabolic and regulatory responses of Yersinia pestis to iron starvation. BMC Microbiology 2010 10:30.

\section{Submit your next manuscript to BioMed Central and take full advantage of:}

- Convenient online submission

- Thorough peer review

- No space constraints or color figure charges

- Immediate publication on acceptance

- Inclusion in PubMed, CAS, Scopus and Google Scholar

- Research which is freely available for redistribution

Submit your manuscript at www.biomedcentral.com/submit
Ciomed Central 